\title{
Radical Succession: Hagiography, Reform, and Franciscan Identity in the Convent of the Abbess Juana de la Cruz (1481-1534)
}

\author{
Pablo Acosta-García
}

check for updates

Citation: Acosta-García, Pablo. 2021 Radical Succession: Hagiography, Reform, and Franciscan Identity in the Convent of the Abbess Juana de la Cruz (1481-1534). Religions 12: 223. https://doi.org/10.3390/rel12030223

\section{Academic Editor:}

Steven Vanderputten

Received: 1 March 2021

Accepted: 12 March 2021

Published: 23 March 2021

Publisher's Note: MDPI stays neutral with regard to jurisdictional claims in published maps and institutional affiliations.

Copyright: (c) 2021 by the author. Licensee MDPI, Basel, Switzerland. This article is an open access article distributed under the terms and conditions of the Creative Commons Attribution (CC BY) license (https:/ / creativecommons.org/licenses/by/ $4.0 /)$.
Institute of Medieval History, Heinrich-Heine-University Düsseldorf, 40225 Düsseldorf, Germany; pablo.garcia.acosta@gmail.com

\begin{abstract}
In this article, I study in depth the first vita of the Franciscan Tertiary abbess Juana de la Cruz (Vida y fin de la bienaventurada virgen sancta Juana de la Cruz, written c. 1534), examining it as a chronicle that narrativizes the origins and reform of a specific religious community in the Castile of the Catholic Monarchs. I argue that Vida y fin constitutes an account that was collectively written inside the walls of the enclosure that can help us understand themes, motifs, and symbolic Franciscan elements that were essential for the self-definition of its original textual community. I first discuss the narrative of the convent's foundation and then examine the penitential identity of the community, highlighting the inspiration that Juana's hagiography takes from the infancy of Caterina da Siena, as described in the Legenda maior by Raimondo da Capua, and analyzing to what extent the represented penitential practices related to the imitatio Christi reflect a Franciscan Tertiary identity in opposition to a Dominican one. Finally, I address the passages in which the hagiographer(s) discuss(es) the sense of belonging to the Franciscan order rather than the Dominicans, and the mystical figure of Francesco d'Assisi as a founder, guide, and exemplar.
\end{abstract}

Keywords: Juana de la Cruz; Franciscan Tertiaries; reform; women mystics

\section{Introduction. Juana de la Cruz in the Context of the Cisnerian Reform}

The incipit of the first hagiographic account of the life of Juana de la Cruz (1481-1534), Vida y fin de la bienaventurada virgen sancta Juana de la Cruz (henceforth Vida y fin), defines the protagonist as a "... nun who professed the four vows in the order of the Holy Saint Francis, in which she lived perfectly and saintly" (" ... monja que fue professa de quatro botos en la orden del señor sant Francisco, en la qual vivió perfeta y sanctamente", f. 1r). ${ }^{1}$ This one-sentence depiction of a Castilian Franciscan visionary whose abbacy was developed at the beginning of the 15th century overlooks an essential detail: although she initially made her profession as a Franciscan Tertiary, the main reason to consider her a nun is directly related to the fourth vow, mentioned later, that of enclosure. ${ }^{2}$ In fact, at the time when Vida y fin was written, shortly after her death (Graña Cid 2017, p. 18), the community had been affected by the Cisnerian reform, which had transformed the former Tertiary convent into a community whose life was framed most probably with a variation of the Urbanist rule

1 I discuss later in this section the unicum of Vida y fin, kept in the Royal Library of El Escorial with the signature K-III-13, ff. 1r-137r. I use the edition by (Luengo Balbás and Requena 2019), published in the Catálogo de santas vivas (http:/ / catalogodesantasvivas.visionarias.es/index.php/ Juana_de_la_Cruz, accessed on 8 September 2020), under the project of the Spanish Ministry of Education 'Catálogo de santas vivas (1400-1550): hacia un corpus completo de un modelo hagiográfico femenino' (PID2019-104237GB-I00) in which I collaborate. The English translations are mine (unless I note otherwise) and for the Castilian text, I reproduce the aforementioned edition without modernizing the orthography or changing the punctuation. For a biography of Juana which takes into account the majority of the extant sources, see (Triviño 2019).

2 The bibliography devoted to Juana and the Convent of Cubas de la Sagra from (Surtz 1990, 1995) is huge and is still growing. Especially important are the contributions by María del Mar Graña Cid, Ángela Muñoz Fernández and Jessica Boon that I will quote in the following pages. 
for the Poor Clares (Triviño 2004, p. 1257). ${ }^{3}$ I will argue in the following pages that Juana's hagiography is a collective chronicle of the convent narrated from the point of view of a community that had experienced the reform, that was living under its effects, and which preserved a strong Franciscan penitential identity.

As is well known, approximately twenty-five years before her death, Juana de la Cruz was actively involved in the reform of the community of Franciscan Tertiaries living in the Convent of Santa María de la Cruz in Cubas de la Sagra (Toledo), where she developed her public activity as a visionary and as a prophetess (Graña Cid 2017, p. 16). In order to contextualize her active role in the transformations of her convent, I will need to address the politics of the religious communities of Castile at the end of the 15th century, because this is essential to reconstruct the context in which Juana and her sisters lived and to connect it to the wider European movement of the Observance (Mixon 2015, pp. 60-84). ${ }^{4}$ In 1494, the Catholic Monarchs commissioned a powerful Observant Provincial, Francisco Ximènez de Cisneros, to reform the Poor Clares of Castile (García Oro 1980, pp. 280-84 and 289-90; Omaechevarría 1972, pp. 114-18). The following year, they went further and ordered him to reform all the female religious houses of the realm (García Oro 1971, pp. 253-54). ${ }^{5}$ The convent of Juana de la Cruz was no exception. It was founded in 1449 as a casa de beatas (a house of Castilian mulieres religiosae) and located on a spot where the Virgin Mary miraculously appeared to a child called Inés Martínez while she was herding pigs. ${ }^{6}$ In approximately 1464, the young and unregulated community started to follow the Third Regular Order of Saint Francis (Graña Cid 2004, p. 308) and this is the context in which a young Juana de la Cruz professed in 1497, in circumstances that Vida y fin narrates and which I analyze later. The Province of Toledo, like the rest of Castille, was following the general tendency of transforming the communities of Franciscan Tertiaries into a more institutionalized branch of the order (García Oro 1971, pp. 249-50; Graña Cid 1994a, pp. 668, $675 ; 1998$, pp. 157-200; 2008, pp. 141-42). The reform was implemented along with many significant changes, the main one being that the community of Cubas de la Sagra added the vow of enclosure to its three original ones (poverty, chastity, and obedience) - that is to say that the members of the community became (at least officially) cloistered nuns (Pedro de Salazar [1612] 1977, VI, f. 442). Juana, who as a novice experienced a series of visionary phenomena, was appointed abbess in 1509 and certainly collaborated with Cardinal Cisneros in undertaking the reform of her convent (Graña Cid 2004, pp. 309-10; Muñoz Fernández 2016).

In this article, I will examine the first vita of Juana de la Cruz-the aforementioned Vida $y$ fin - as a chronicle that narrativizes the origins and subsequent life of a particular community. I will claim that Vida y fin constitutes an account written inside the walls of the enclosure that could help us understand not only the effects of a specific process of reform from a group perspective, but also the elements of self-definition in that collective. As Graña Cid (2017) has demonstrated, Juana's hagiographical account contains some essentially problematic elements, because it take sides in some of the conflicts around

3 In general, on the so-called Castilian pre-reform, see (Bataillon [1937] 1996, pp. 1-83) and (García Oro 1971). For a description of the main traits of the Cisnerian Constitutions for the Convent of San Juan de la Penitencia, see (Graña Cid 1994b, p. 126). On the discussion about of its adoption in the Convent of Santa María de la Cruz, see below, Section 2.1.

4 On the low-medieval reformist movements of the religious life in Castile, see (García Oro 1980, pp. 211-90). In general, about the controversy between conventuals and observants, see (García Oro 2005, pp. 235-53). In particular, about the history and development of the conventuals, see (Redondo 2005, pp. 273-96).

5 On this matter, the overview given by (García Oro 1980, p. 289) is very helpful: “Cisneros tuvo, en este caso, una intervención más directa y constante que la arriba reseñada respecto a las casas masculinas. Nombrado reformador de las clarisas de Castilla el 20 de julio de 1494 y de los monasterios femeninos de Castilla en general el 13 de febrero de 1495, conseguía en 1497 autorización pontificia para introducir en los monasterios el régimen trienal (breve Cum sicut nobis, de 21 de mayo de 1497); someter los monasterios reformados de cada orden a la respectiva familia observante (breve Ex iniuncto, de 23 de octubre de 1497); ejercer en ellos la jurisdicción de los visitadores generales (breve del mismo título y fecha) y destinar a los monasterios femeninos reformados los bienes de los conventuales franciscanos pasados a la Observancia (breve Cum sicut, de 31 de mayo de 1502)."

6 On the beatas, see (Graña Cid 1994a) (Muñoz Fernández 1994, pp. 89-152; 1998) (Graña Cid 2008, pp. 392-421) (Graña Cid 2018) (Braguier 2019). In particular in the context of the Castilian mysticism, see (McGinn 2017, pp. 11-61). 
Juana's abbacy, which were directly related to the new customs adopted in the convent. ${ }^{7}$ In this respect, examining the Vida y fin as a story told from the point of view of the reformed community (or, at least, from that reformed nuns who had supported Juana) will allow the discussion of a self-expressed group identity in contrast to the later and more general Franciscan chronicles that tend to use the Tertiaries to formalize the legendary origins of the order (More 2015, esp. pp. 90-91).

The creation of this narrative seems to allow the nuns of the Convent of Santa María de la Cruz to construct their collective memory and, ultimately, to reinforce their own idiosyncrasy through a series of symbols embodied in the attributes and life events of their abbess. ${ }^{8}$ This can be seen as a characteristic shared with certain Observant Franciscan feminine communities in Italy (Zarri 2011, p. xiii):

Come avviene anche in altri casi, e in particolari nei monasteri osservanti, a partire del Quattrocento le monache acquistano maggiore coscienza della propria identità, contrassegnata da una piú rigorosa disciplina, e intraprendono la stesura di chronache monastiche il cui fine è quello di fare memoria del proprio modus vivendi e delle religiose che vivono santamente.

Accordingly, I will develop a narrative analysis where the hagiographical themes and motifs will be decoded, taking into account their possible meaning at the level of a collective chronicle written as a story of origin. The author of this text-a role traditionally assigned to María Evangelista, a nun contemporary with Juana's abbacy (García de Andrés 1999, pp. 17-28) - builds a chronicle of the convent based on two foundation stones-the abbess Juana de la Cruz as a heroic figure designated by grace as a leader and the process of reform that she promoted (or helped to carry out until it succeeded) - that need to be understood from a complex point of view. ${ }^{9}$ Therefore, I will also argue that the whole vita is permeated by its protagonist and her divine aim of reforming the life of the convent. Indeed, I will argue that the hagiographically codified figure of the charismatic abbess articulates an account in which she plays the role of the reform's main agent and in which her visionary activity finds full justification.

The only extant manuscript of the Vida y fin is kept in the Royal Monastery of El Escorial and we do not know anything about its earlier provenance. ${ }^{10}$ It is a medium-sized book $(215 \times 155 \mathrm{~mm})$ and, as García de Andrés (1999, pp. 17-20) has demonstrated, it is not the copy attributed to María Evangelista that was in the convent's library because it does not coincide with the historical descriptions of this original kept by the nuns. The date of the handwriting (16th century) is the same as the estimated date of the text's composition: after 1534, soon after Juana's death and during María Evangelista's life. ${ }^{11}$ Other sources for studying the history and customs of the Convent of Santa María de la Cruz have been terribly reduced, notably through the complete destruction of its library and archive during the Spanish Civil War (Temperini 1998, pp. 47-48). ${ }^{12}$ Luckily, the interest aroused by

7 See also (Surtz 1990, 1995).

8 About the "scrittura communitaria" in relationship to mystical writing, see Zarri (2014, pp. 53-54). For the community memory related with writing, see (Zarri and Leturio 2011). For an example of a non-Castilian hagiography analyzed from a similar perspective, see (Sancho Fibla Forthcoming).

9 The vision of a homogeneous reform in which Cisneros had an iconic centrality was early refuted by (García Oro 1971, pp. 171-72). For a revision of the concept of religious reform in medieval and pre-modern Castile, see (Pérez Vidal 2015, 2021). For a perspective of the monastic reforms as complex processes, see (Vanderputten 2013).

10 The main catalog descriptions are: that of the electronic catalog of the Royal Library of El Escorial (https://rbmecat.patrimonionacional.es/cgibin/koha/opac-detail.pl?biblionumber=894\&query_desc=kw\%2Cwrdl\%3A\%20vida\%20y\%20fin (accessed on 18 February 2021), which references the classic manuscript description by (Zarco Cuevas 1924-1929, II, pp. 99-105). Philobiblon (text id 1283 (accessed on 18 February 2021) takes its information also from this last reference and notes an error in the date of the possible composition of the text: Zarco Cuevas dates the composition to between "1401-1500", which is not possible because of the year of Juana de la Cruz's death (1534), which must be the date of copy "a quo".

11 Information given by the electronic catalog of the Royal Monastery of El Escorial (accessed on 18 February 2021): “Nota Fecha/Imprenta: Letra del s. XVI".

12 "[The convent s]ufrirá las consecuencias de los avatares históricos y políticos del país, como, invasión de las tropas francesas, desamortización de Mendizábal o su destrucción en la Guerra Civil, siendo destruidos, no sólo, su fábrica, sino también su biblioteca y su archivo" (http: // pares.mcu.es/ParesBusquedas20/catalogo/autoridad/7165, accessed on 24 December 2020). Currently, the Archivo Histórico Nacional (Madrid, http://pares.mcu.es/ParesBusquedas20/catalogo/description/1675364, accessed on 24 December 2020) keeps only documents from the 17th to the 19th centuries. 
the figure of Juana de la Cruz during her life and after her death generated a process of canonization that included the testimonies of contemporary witnesses and numerous hagiographical accounts (Gómez López 2004; Zugasti [2011] 2017). Beyond these sources, historiography has worked mainly with three very important texts: a collection of seventytwo visionary sermons transcribed during Juana's life entitled Libro del Conhorte (The Book of Consolation, henceforth Conhorte), compiled before 1525 (Graña Cid 2017, p. 18) and kept in two different copies; ${ }^{13}$ a collection of some of the traditions and customs of the convent with a performative character generally known as Libro de la casa (Book of the House) ${ }^{14}$, and the aforementioned first hagiography of Juana, Vida $y$ fin. Both the composition of this last work and the transcription of the Conhorte have been traditionally assigned to María Evangelista. One of Juana's most important biographers, Navarro [1622] (1659, pp. 239-40), presents her one century later following the testimonies of two nuns who had met her while she was alive:

... y el año en que esto se escribe, que es de 1617, viven algunas religiosas ancianas en él, que son las madres Ana de la Concepción y María de la Purificación, las cuales alcanzaron a la dicha sor María Evangelista, y de su boca oyeron muchas veces, que milagrosamente había alcanzado del Señor la tal gracia, para escribir la Vida de la santa Juana de la Cruz, que se guarda en un libro mediano y los sermones que predicó por discurso de un año, que se guardan en otro mayor de folio, intitulado Libro del Conorte [ . . . ] [María Evangelista tenía] tan fiel y tenaz memoria que en acabando de oír el sermón de la Santa Juana, iba y le escrivía luego puntualmente, con ser todos de revelaciones muy escuras y misteriosas, y algunos tan largos que tienen a ocho, y diez pliegos, llenos de Teología Escolástica y mística, y de muchas autoridades de la Escritura Sagrada.

The depiction of Evangelista's miraculous literary skills very probably follows the model of the life of Caterina da Siena, as codified in the Legenda maior by Raimondo da Capua (Mooney 2013). ${ }^{15}$ This hagiographical topos was a typical characteristic of the sante vive related to the Cisnerian milieu and their Italian counterparts. ${ }^{16}$ In addition to the numinous character which this fact adds to the textual artifacts related to Juana (even at an apotropaic level, as shown in the quotation in the following footnote), it also could have been used to justify literacy inside the convent as an act of grace. ${ }^{17}$ In fact, María's chosen name (Evangelista $=$ Evangelist) seems to point to the figure of the (male) writer inspired by the grace of God. Furthermore, the quoted fragment adds a second miracle linked to the act of writing: the "fiel $y$ tenaz" (faithful and persistent) memory of the nun, capable of remembering by heart the sermons pronounced by Juana and writing them down later. We should keep in mind that Juana used to preach in sessions that lasted approximately six hours and that these performances took place over thirteen years (Vida y fin f. 28r; f. 31r). While it is possible that María Evangelista wrote an adaptation of what she witnessed, it seems more likely that the extant sermons represent a work of reportatio of different sessions (probably combining various sermons on the same topic given in different years) which were later put together in a coherent piece, as some testimonies from the process of

13 Edited by (García de Andrés 1999), who discusses the two manuscripts in (García de Andrés 1999, pp. 69-74). There is an English selection and translation with a solvent introduction: (Boon and Surtz 2016).

14 This manuscript is kept in Biblioteca Nacional de España with the signature MSS-9661. It has been edited by (Curto 2018).

15 On Caterina's literacy, see also (Luongo 2013) and (Tylus 2013).

16 For instance, Lucia da Narni; see (Matter and Zarri 2011, p. 76).

17 The following fragment is a clear example of María Evangelista's role as a scribe and keeper of the sacred books: “Una religiosa que se llamava María de la Madre de Dios tenía gracia de arrobarse. Vio una vez entrar por la puerta de la iglesia a María Evangelista, que era ya difunta, con el libro que escrivió, que se llama Santo Conorte de los sermones que el Señor predicó por la voca de nuestra madre santa Juana, la qual dixo que era de oro; y en la otra mano, una cruz verde. Y esta señora María Evangelista no sabía escrivir, y el Señor le dio gracia para que escriviesse el santo libro, y dixo a esta religiosa que la vio cómo el Señor le avía dado mucha gloria porque le havía escrito. Treze años predicó el Señor y de solos los dos postreros se escribió este santo libro. A persuasión del sancto ángel Laruel, púsole el Señor este título de Conorte y concediole el Señor muchas bendiciones y virtudes contra los demonios y tempestades, que mandó el santo ángel que quando alguna estubiesse en pasamiento le pusiessen algo de la lectura d'este libro para defensa del demonio. Y en las tempestades manda la prelada saquen el santo libro o sus traslados, y se ha visto cesar la tempestad muchas vezes" (Curto 2018, ff. 20r-20v). See also (Triviño 1999, p. 104). 
beatification assert. ${ }^{18}$ If we also consider that it is very likely that María Evangelista was not the sole transcriber of these sermons, but merely one of several (Triviño 1999, pp. 103-4, 108; Boon 2016, pp. 15-16), we should probably re-evaluate her idealized role as the unique scribe of Vida y fin. This collective character of the revealed works of a prominent figure of the convent could have followed patterns of work related to prophetic authority present in nunneries from at least the 13th century (Hubrath 1999), and this is important for the argument of these pages, mainly because Vida $y$ fin surely includes the vision of the nuns as a textual community (Cátedra 2005, p. 15). In this sense, the legendary role that they ascribed to Juana as abbess, leader, and reformer is shared with that of María Evangelista as the sole transcriber or writer.

In the following section, I analyze some passages of the text in depth. It is subdivided into three subsections. In the first, I discuss the narratives of the foundation of the casa de beatas, demonstrating that the origins and early development of the community are narrated from the perspective of the later reform. In the second, I examine the penitential identity of the community-which remained even after the taking of the fourth vowthrough the figure of Juana. Finally, I address the passages in which the hagiographer(s) discuss(es) the sense of belonging to the Franciscan order rather than the Dominican and the mystical figure of Francesco d'Assisi as a founder, guide, and exemplar.

\section{Textual Analysis}

\subsection{The Foundation of the Beaterio, and Juana's 'Virile' Childhood}

The opening paragraphs of Juana's spiritual biography need to be read as an origin story of the convent itself. As noted above, the foundation of the house of beatas in Cubas de la Sagra was mediated by apparitions of the Virgin Mary to the child Inés, who was herding pigs. It is a story that works through a chain of intercessions-Christ, Mary, Inés, and later Juana - and it starts in medias res with a familiar conversation between the Virgin Mary and Christ, reminiscent of those transcribed in the visionary sermons of the Conhorte (Vida y fin, f. 1v). The Virgin Mary asks her son for permission to found a casa where "He and She were served and their divine cult was venerated and served, and it [the religious house] and its vocation would be remembered forever" ["Él y Élla fuesen servidos y estuviese su culto divino reverençiado y servido y huviese memoria para siempre della y de su bocaçión" (Vida y fin, f. 1r)]. After discussing it with his mother, Christ finally gives authorization to found the house through the presence of a feminine intermediary (medianera), Inés. After a few revelations by the Virgin, the child announces to the faithful that a house must be built in the place of the miracle by the will of the Virgin Mary. When the building is finished, a group of religious women and Inés herself start to live there. However, as the next paragraph shows, the early promises of virtue are broken:

And sometimes this holy Inés had revelations and spiritual consolations, and the Devil used to appear to her with a scourge in his hand, and he used treat her very cruelly and harshly, and among other things he used to say: "I won't stop until I destroy you," and he used to disdain her and even torment her bodily. And Inés used to fight as best she could. And the old serpent, using all his malice and astuteness, caused her huge and hard temptations for some time. And when she lost her spiritual virtue and the strength to beat her adversary, she fell into sin and lack of virtue, in such a way that she herself dug a hole into which she then fell, along with some sheep of the house that Our Lady had given her to manage and help to save them.

Y algunas vezes tenía esta santa Ynés rebelaçiones y consolaçiones espirituales, y apareçiole el Demonio con un azote en la mano, y amenazávala muy cruda y ásperamente, y le dezía a vueltas de otras cosas: "No çesaré de travajar basta que te destruyga", y hazíale muchos despechos y aun tormentos corporales. Y esta Ynés esforçávase como

18 “Decía, dicha María Evangelista, que escribió al dictado de dicha sierva de Dios Juana de la Cruz en los últimos años de su vida, cuando permanecía en el lecho, tullido todo el cuerpo y los pies y las manos" (apud García de Andrés 1999, pp. 24-25). 
podía. Y la antigua serpiente, con toda su maliçia y astuçia, le causó muy grandes y rezias tentaçiones por algún tiempo. Y faltándole a ella virtud spiritual y fuerça para vençer a su adversario, cayó en algunos peccados y falta de virtud, de manera que ella propia hizo oyo en que ella cayó, y algunas ovejas de la casa que Nuestra Señora le havía dado para que las administrase y ayudase a salvar.

(Vida y fin, ff. 1v-2r)

Thus, as early as the second folio of this life, the medianera-who during her life in the community is described as a recipient of revelations and spiritual consolations ("rebelaçiones y consolaçiones espirituales") — fails in her leading role. At this point, the figure of Inés, the little shepherdess, is represented as precisely a shepherd who has fallen into a hole, by reason of sin, dragging along with her some of the "sheep" (ovejas) of her community. This account implies the failure of the feminine intermediary (medianera), not as the promoter of the foundation but as a leader of the community, which was then living in decadence. Of course, at this stage of the account, the "elephant in the room" is Juana, who is called upon to replace Inés, taking over her roles as a charismatic and a leader, and undertaking the reform of the religious house:

[The Virgin Mary] entreated her holy son Jesus Christ, Our Lord, one more time with great charity and humility that, by his Divine Majesty, he might be pleased to restore the honor of his holy appearance and the virtue of his house, which had fallen and was in need of his powerful hand to raise a more perfect creature than the first one to whom she had appeared. And that this creature's function was to restore the falling of the others and to raise devotion to her appearance and virtue in the nuns who lived in the house, and that she was called Juana, which is a gracious name, and she was full of gratitude.

[The Virgin Mary] tornó a suplicar a su preçioso hijo Nuestro Señor Jesucristo con muy gran charidad e humildad que quisiese su Divina Magestad haçer de manera que fuese restaurada la honra de su sancto apariçimiento y la virtud de su casa, la qual estaba muy caýda, y hera menester que su poderosa mano criase alguna criatura más perfeta que la primera a quien ella se apareçió, y que fuese esta que criase para restaurar la caýda de las otras y levantar la devoçión de su apareçimiento y virtud en las monjas abitadoras de su casa, y que fuese llamada Juana, que es nombre de graçia, y ella llena de gratitud.

(Vida y fin, f. 2r)

As we can observe, the beginning of the account is built on a simple plot that plays with a topos which opposes virtue/sin as spatial polarities (high/low), where the second is reinforced through the traditional expression of a "fall". The promise of the advent of a kind of a second founder who will "restore the falling of the others" (the rest of the community, "restaurar la caýda de las otras") and raise ("levantar") both devotion to the Virgin and the virtue of the nuns ("y levantar la devoçión de su apareçimiento y virtud en las monjas") is essential. It is worth mentioning two details here. First, this account not only gives the origins of Juana but also those of the convent. This verbal "re-foundation" is achieved by developing a narrative in which the original intercessor (Inés) fails in her duties and is replaced by Juana. This radical succession is blessed by the Virgin Mary and makes Juana the heiress to a relationship based on the Virgin's visionary appearances, transforming her into the new mediator for the community. The evidence that this shifting of powers works in the long run is confirmed by an episode developed in the Libro de la casa (Curto 2018, ff. 34v-36r), where Juana is the recipient of the revelations of Mary, and some of the visionary sermons in the Conhorte dedicated to the Virgin (see for instance, García de Andrés 1999, pp. 357-82, 1081-104). The second aspect is that this story about falling and restoration shapes Vida $y$ fin as a chronicle of the later reform. In fact, when Juana escapes her family house to enter the convent, she has a vision of the Virgin Mary, who pronounces these significant words: "I give you the keys of my house, so you can dwell in it, and lead, and make the evil disappear and cut it off, and increase the service to my adored son and to me" ("yo te doy las llaves de mi casa para que en ella estés y mandes, y 
disipes y cortes lo malo, y aumentes el serviçio de mi preçiado hijo y el mío" (Vida y fin, f. 11v, my emphasis). Here, the discourse about the reforming role of Juana is made explicit: the Virgin has mediated between Christ and the community, not only to choose her as a new leader ("estés y mandes") but also to renovate the customs of the decadent convent ("disipes $y$ cortes lo malo").

From this point until halfway through the third chapter of Vida y fin (f. 13v), the hagiography focuses on Juana's childhood. The account is typically developed by mixing historical information specific to Juana's case and hagiographic themes, which need to be read in the context of the common models of sanctity of the period. ${ }^{19}$ As I will explore in the next subsection, the biggest influence is probably the Legenda maior of Caterina da Siena by Raimondo da Capua (Huerga 1968; Ahlgren 2000; Sanmartín Bastida 2013). As I have shown elsewhere, this title was circulating widely with others by/on different European charismatic women in Castile at least from the end of the 15th century, especially in the Cisnerian milieu and related to the reform undertaken by the Catholic Monarchs. In the specific case of Vida y fin, there is a large number of hagiographical themes that coincide with the Sienese saint and which are grouped especially in her infancy, tracing a portrait with the main lines of what Vauchez (1988, p. 247) called "les contours de la sainteté laïque feminine". For instance, her origins in a clean family not pertaining to the aristocracy ("good and Christian parents, virtuous and clean in their habits, and people in the middle way," = "padres buenos y christianos, y virtuosos y limpios en las costumbres, y de gente de mediana manera", Vida y fin, f. 3r), a life-turning event at seven years (her mother's death), and the virtue of the soul reflected in the girl's corporeal beauty ("She was endowed with a much grace and bodily beauty" = "Fue dotada de mucha graçia y hermosura corporal", Vida y fin, f. $2 v) .{ }^{20}$ Regarding this bodily beauty, Vida y fin introduces a striking characteristic: Juana's "virility". The theme of her masculine attributes is preceded by a short narrative bridge in which Jesus Christ gives her supernatural abilities. From a hagiographical perspective, it is curious that Juana's childhood starts in her mother's womb:

And as his Divine Majesty gave the holy mother the virtue that he was sending her, the blessed Juana de la Cruz was at that moment in the womb of her mother starting to be made male, [and God] made her woman as [an] all-powerful [God] could and can do. And his Divine Majesty did not want to take away the knot that she had in her throat so that it would be a testament to the miracle. (Translation by Boon 2018, p. 265, completed by the present autor)

Y como su Divina Magestad otorgó a su sancta madre la virtud que le mandava, y la bienabenturada Juana de la Cruz estava entonçes en el vientre de su madre enpezada a façer varón, tornola muger, como pudo y puede haçer como todopoderoso. Y no quiso su Divina Magestad deshazerle una nuez que tenía en la garganta, porque fuese testigo del milagro. (Vida y fin, f. 2v)

The passage was initially highlighted by Surtz (1990, p. 7), where he calls the Adam's apple "the emblem of a divinely determined androgyny." As Boon (2018) has noted, the explicit protuberance also points to the "mixing of genders" in the figure of Christ (Graña Cid 2009, pp. 490, 530), which is found not only in various places in the living saint's hagiography but also in her sermons. Thus, this visual sign locates the future abbess in an ambiguous gendered place which, not by chance, finds its main precedent in Raimondo da Capua's Second Prologue to Caterina da Siena's Legenda: “Truly, I saw an angel who was descending from the sky. Because this Virgin of whom we speak here was not so much a woman as an angel in the earth or, if you wish me to say more, she was more a celestial man than a woman." ("Por cierto, yo vi un ángel que descendía del cielo. Porque esta Virgen, de quien aquí decimos, no era mujer más ángel en la tierra, o si más quieres, más era hombre

19 On decoding the hagiographies of late-medieval women as fusions of biographical narratives and symbolical themes, see (Cirlot and Garí 2008, p. 181).

20 These topics in Raimondo da Capua's Legenda maior and the vitae of different sante vive of the Cisnerian period (mainly, María de Ajofrín, María de Santo Domingo, and Juana de la Cruz herself) are analyzed comparatively in (Acosta-García 2021). 
celestial que mujer"). ${ }^{21}$ Therefore, from the point of view of the narrative logic, this scene provides an irrefutable argument for the leading role that she must have for the future of the community, because masculine attributes in the fetus justify an authority granted by grace. The location of this information, literally at the beginning of Juana's life, gives a picture of how sensitive it might have been for the chronicle of the community. As Boon (2018, p. 266) exemplarily synthetizes it:

According to her semi-autobiography, then, Juana comfortably inhabited multiple gender dynamics, ranging from being transgendered as a fetus while retaining a male secondary sex characteristic, to cross-dressing, to voice register changes when Jesus gave sermons through her enraptured body, all of which experiences she claimed to be authorized by the Virgin Mary and enabled by God. These gender dynamics were central to the construction of Juana's authority in her Marian convent-she was born fe-male to be its abbess-while also giving Juana a platform from which she could preach, or rather by which Jesus could speak through her.

This way, the new leader is seen as appointed by grace because she shows a visible attribute that proves her supernatural authority. ${ }^{22}$ This kind of visible corporeal mark (in many respects similar to the stigmata, which I discuss later) will be characteristic of the future abbess's narrative: once the text has presented her as the chosen successor to undertake the reform, she will be constructed as an exemplar of penitent behavior.

\subsection{Penitential Identity}

Before starting my textual analysis of penitential identity, it is important to note that the rules followed in Juana's convent are currently the subject of debate. In his groundbreaking book on Juana and the Conhorte, Surtz $(1990$, p. 3) seemed to have a clear idea of the rules followed before and after the reform. ${ }^{23}$ Of course, after the conversion of the beaterio into a convent, the nuns should have followed a Franciscan Tertiary rule, perhaps the Supra montem (1289). ${ }^{24}$ However, as Graña Cid (2004, pp. 309-10) has stated, after the Cisnerian reform the convent became an ambiguous place that housed female Franciscan Tertiaries, but under a rule which constricted them to the enclosure. According to this author, the questionable status of the nuns also affected the rule they followed: "the convent was not completely monasticized but maintained a relatively undefined regular status" ("no se dio la monacalización completa del monasterio, que mantuvo un estatus de relativa indefinición regular"). On the other hand, if we take a closer look at the context of the Cisnerian reform of female Franciscan communities in the diocese of Toledo, there was a group of Franciscan convents founded or reformed by the Cardinal which had health care and educational functions (Abad Pérez 1968; Graña Cid 1994b). For one of these-San Juan de la Penitencia in Alcalá de Henares-he wrote and promoted some Constitutions in 1508. This document was based on the Urbanist rule but reinforced its penitential aspects (Graña Cid 1994b, p. 126). The same Constitutions were later adopted by the nuns of San Juan de la Penitencia in Toledo, also Franciscan Tertiaries, and had to be modified after the Cardinal's death (1518) because of their hardness (Abad Pérez 1968, p. 4). Triviño (2004, p. 1257, n. 12) considers that Juana's convent also used these Constitutions and, as

21 For various reasons which I explain in (Acosta-García 2020a, p. 149), when studying the hagiografies of the charismatic women of the reign of the Catholic Monarchs, it make sense to quote Raimondo da Capua's Legenda maior using the Castilian translation (Raymundo de Capua 1511) (henceforth, Vida. In this case, Vida, Prólogo, [f. 2r]). In this edition, the two Prologues preceding the Vida are not numbered.

22 For an in-depth discussion of the gender and theological implications of this motif, which exceeds the argument of these pages, see the entire (Boon 2018).

23 "In 1464, a group of beatas occupied a nearby house, where they lived uncloistered under the rule of the Secular Third Order of Saint Francis. Later in the century, under the auspices of Cisneros the convent became cloistered and adopted the rule of the Regular Third Order of Saint Francis."

24 See the bull's text in (Svaraglia 1759-1788, pp. 94-97). For the Supra montem and the Castilian Franciscan tertiaries, see (Graña Cid 2008, p. 393). As she discusses later in the same work (2008, pp. 410-17) almost all the communities of Castilian female Franciscan tertiaries followed "los ordenamientos regulares formulados en su día (siglo XIII) para las fraternidades penitenciales y [ ... ] muchas de ellas contaron con estatutos de ordenaciones propios que completaban las reglas en aquellas necesidades suscitadas por la vida común a las que no podían ofrecer respuesta." 
we will see, if we read Vida y fin carefully it is possible to find some traits that seem to confirm this. It seems likely that the new cloistered community operated under a variation of the Urbanist rule while keeping, at the same time, a strong penitential background. ${ }^{25}$

In this sense, Vida y fin describes Juana's entering the convent from a collective perspective: that of the group projecting its ideals onto the child. Therefore, the portrait that we find of Juana once she had taken the habit seeks to highlight characteristics that were essential for the community at the time in which this hagiography was written. The essential lines of the reform of the convent's customs are drawn through Juana's behavior. In my opinion, there are two clear subtexts to this description: first, some Franciscan rules in which the new group's relationship to issues such as clothing, fasting, and silence are codified and, second, a very specific collection of texts on/by medieval penitent visionary women that were widely circulating in Cisnerian circles at the time (Acosta-García 2020a, $2020 \mathrm{~b}, 2020 \mathrm{c})$. The existence of the first subtext is easy to check in the sentences right after the moment when she takes the habit:

And her mistress was instructing her about what she needed to keep, according to God and the rule of her order, which the nuns promise to keep, and telling her that she needed to be silent for a whole year, that she should not speak except only with the superiors and with her, and at the time of confession. She liked this silence so much because she was by nature a great friend of it. And, in this way, she started to make a wonderful and beneficial life for everybody who knew her and who listened to her words.

Y administrándola su maestra de las cosas que havía de guardar, según Dios y la regla de su orden, que en la profesión prometen de guardar, dijole que havía de tener silençio todo un año, que no havía de hablar sino con las perladas y con ella, y quando confesase; del qual silençio ella holgó mucho, porque de natural hera muy amiga d'el. Y ansí empezó a hazer vida marabillosa y muy provechosa para los que la savian e oýan. (Vida y fin, f. 13v)

On the one hand, the existence of a mistress of novices instructing Juana about the importance of silence as part of the community life supports the idea that Juana's convent followed a variation of the Urbanist rule, ${ }^{26}$ which not only clearly establishes the role of this figure in the education of novices but also notes the importance of silence as a typical trait of monastic life, in clear contrast to the First Rule of Clare (Triviño 2011, pp. 434-36). On the other hand, the text establishes an explicit link between Juana's innate silence and the behavior codified in the community's rule. This silent attribute forms part of the enumeration of the penitential virtues of Juana which is constructed by imitating some late-medieval hagiographical models that I will examine below. After the fragment quoted above, Juana's virtues are presented in short descriptive blocks in the following order: clothing, silence, fasting, and sleeping habits. This dispositio resembles the division by topic chapters of some Franciscan rules and it touches on essential points for a community reformed during Juana's abbacy. For example, talking about Juana's clothing, the text reads:

Her clothes were very humble and poor, much more so than those of the other religious women. She was wearing a tunic made of coarse wool and a very old and darned skirt. The same for the habit, and she wore espadrilles on her feet. And most of the time she used to walk barefoot, and with a very thick cord clinging to her. And she used to wear a hairnet on her head[. And] on the top [she used to wear] the vilest that she had and, under this, where nobody can see

25 This idea is supported by (García Oro 1971, pp. 249-50): “En ambos reinos existían numerosos monasterios de beatas de la Tercera Orden que seguían una vida más o menos regular. En la mente de los reformadores y de los Reyes, el mejor medio para reformarlas fue lograr que abrazasen la Regla de Santa Clara. Sin duda, la mayor parte de ellas se decidieron por aceptar la forma de vida de las urbanistas."

26 On the mistress of novices, see "caput III" (Svaraglia 1759-1788, II: p. 511): “Omnes vero ex more intra Claustrum receptae tonsis crinibus citius deponant habitum saecularem, quibus deputetur Magistra, quae eas informet regularibus disciplinis". On silence, see "caput IX" (Svaraglia 1759-1788, II: p. 513): "Silentium continuum sic continue ab omnibus teneatur, ut nec sibi invicem, nec alicui alii sine licentia eis loqui liceat, exceptis iis, quibus magisterium aliquod vel opus injunctum fuerit, quod non possit cum silentio exerceri ... " 
it, a very harsh cilice, which she never took off. These were the very grave and harsh penances that she performed. ${ }^{27}$

Su bestido hera muy pobre e humilde, muy más qu'el de las otras religiosas. Traýa túnica de sayal, e una saya muy vieja y remendada, e el ávito lo mesmo, e unos alpargatas en los pies, e lo más del tiempo andava descalza, e la más gruesa cuerda que ella podía haver se çeñía. Y en la caveça una albanega de estopa[. Y] ençima lo más despreçiado que ella tenía $y$, devajo de esto, que no se lo vía nadie, un muy áspero siliçio, el qual nunca se quitava de noche ni de día. Estas muy graves e ásperas penitençias hazía. (Vida y fin, f. 13v)

This fragment could be included in what Warr (2010, pp. 145-67) calls "the power of clothing" in the mendicant, visionary context of the representation of Caterina da Siena. Evidently, this outfit not only refers to the desire for a correct approach to poverty inside the convent, but also coincides with the spirit of humility codified in various Franciscan rules, including the Urbanist ${ }^{28}$. On the other hand, this reflection in the vita of the spirit of extreme poverty from the origins of the Franciscan movement makes full sense in the context of the Cisnerian Observant reform in the area of Toledo, because as an Observant himself the Cardinal promoted (or, at least, desired) this turn. Included together with the books of Angela da Foligno and Caterina da Siena that he commissioned (Figure 1) is a subgroup of Franciscan legislative documents: the Regula non bullata by Francesco d'Assisi, the First Rule by Chiara, and the Privilegium paupertatis, given to her by Innocent III on 6 July 1216 (Ulibarrena 1994, pp. 214-15). ${ }^{29}$ These Cisnerian references are evidently linked to an active nostalgia that seeks to stimulate the radical poverty of the origins of the order but which, paradoxically, contrasts with the process of institutionalization and its effects-as, for instance, the stable income that Juana received as an abbess through the reformation process (Graña Cid 2004, pp. 18-19).

The synergy between penitential attributes codified in historical Franciscan documents and penitential vitae dedicated to women is constant in the text. As I have written previously, the model of sanctity starting with a holy childhood is established in Castile by Raimondo da Capua's Legenda maior. In general, after collating the hagiographies of Caterina and Juana, it can be asserted that Juana's life follows the Dominican's model of a rigorous puella senex (Acosta-García 2021, pp. 149-58). Specifically, the link established between Caterina's infancy and her virtuous habits is transferred to Juana's life. A clear example of this is the relationship of both sante vive to food: in the first place, the Legenda maior narrates how the future Sienese saint abandons meat progressively, later replaces food with the ingestion of wild herbs, and finally ceases her nourishment absolutely (Vida, ff. IXr-v).$^{30}$ As an early sentence of the vita explains: "Her bodily nourishment was scarce and every day was a little bit less: a most rare thing in a growing person" ("Su manjar corporal era muy poco y cada día era menos como sea contrario muy comúnmente en los que van creciendo en los cuerpos", Vida, f. IIv). ${ }^{31}$ This model is adopted by Juana's hagiographer, as a part of the aforementioned list of virtuous behavior, in dialogue with both the reform and the adopted rule: "Her fasts were most perfect, both spiritually and corporeally, because she not only used to fast from her childhood usually eating only once a day, but was also even used to being three entire days and nights without nourishing her body. And she not only used to fast with eating, but also with sleeping" ("Heran sus ayunos muy perfetos, $e$

27 I have modified the punctuation of the quoted edition.

28 Chapter IV of the Urbanist rule for the Poor Clares deals with the issue of clothing (Svaraglia 1759-1788, II: p. 511): "haec indumenta sint de panno religioso, et vili tam pretio, quam colore." For its part, Supra montem (1289) makes explicit reference to "de humili panno in pretio et colore" which the friars needed to wear, clarifying that in the case of the sisters the level of poverty showed by these clothes could be adjusted (Svaraglia 1759-1788, IV: p. 95): "Circa humilitatem vero panni, et pellitones Sororum ipsarum, juxta conditionem cujuslibet earumdem, ac loci consuetudinem poterit dispensari."

29 These texts are located in the following position: Regula non bullata (= Esser 2013, pp. 122-79) in (Angela da Foligno 1055, ff. CLVIIr-CLVIIIv;) First Rule (= Omaechevarría [1970] 2015, pp. 264-94) in (Angela da Foligno 1510, ff. CIIIr-CXIIIr); Privilegium paupertatis (= Omaechevarría [1970] 2015, pp. 232-36) in (1510, ff. CXIIIv-CXIIIr). About the combination of these legislative texts with the devotional works, see (Acosta-García 2020b).

30 On medieval women mystics and food, see (Bynum 1987). Especifically on the Castilian case, see (Sanmartín Bastida 2015).

31 On Caterina's relationship with food, see also Vida, ff. XCIIv, XXXVIr and XXXVIIr. 
mucho assí espiritual como corporalmente, que no solo usava dende su niñez ayunar ordinariamente comiendo una vez al dí, mas aun estar tres días con sus noches sin tomar ningún mantenimiento corporal. Y no solamente ayunava de comer, mas aun de dormir", Vida y fin, f. 14r). The usual late-medieval combination of fasting and Eucharist-oriented piety is also present in the vitae of both Caterina and Juana. ${ }^{32}$

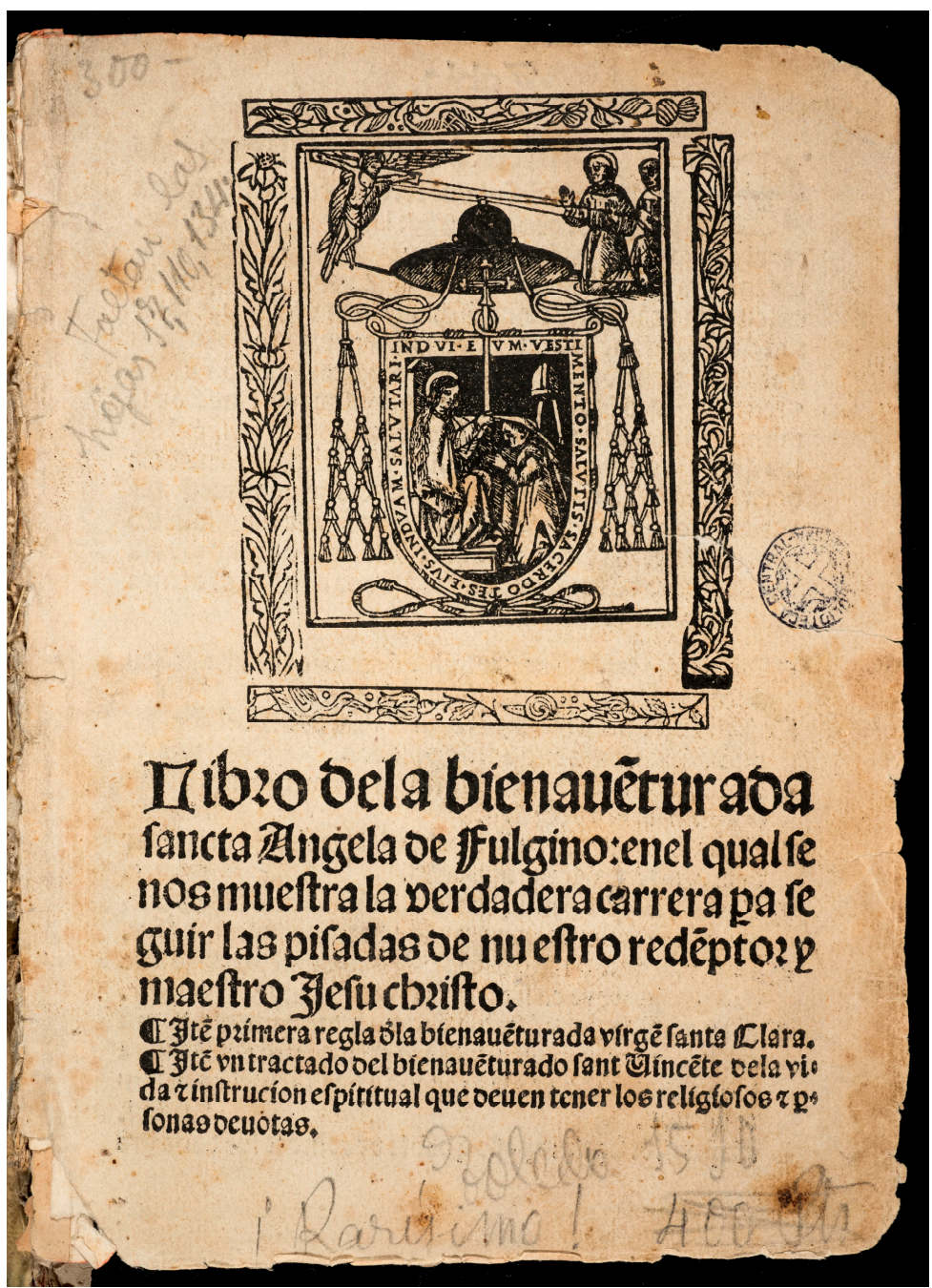

Figure 1. Francesco receiving the stigmata and the Virgin presenting the chausuble to Ildefonso de Table 1510. (= Angela da Foligno 1510); Barcelona, Biblioteca de Catalunya, Res $751-12^{\circ}$, cover.

Thus, in both accounts, there is a virtuous inborn impulse that is developed later by the child as an ascetic element of her personality. Although the biographical base of Juana's hagiography makes it impossible to copy the exact plot that is developed in the vita of Caterina da Siena (Muñoz Fernández 2016, p. 200, n. 29), it is easy to recognize in Vida $y$ fin some codified themes of a feminine, late-medieval model of sanctity. For example, the second chapter focuses on the period after her mother's death, when she was living with her rich aunt and uncle. In their house, she starts to develop a clearly penitential behavior: "And when she used to see the spent candle, in the period of the long and cold winter nights, in order to achieve a greater penitence-together with fervent prayer-she used to take her clothes off in front of certain images, tightening the very harsh cilice that she was

32 Eucharistic miracles are numerous in the text: for instance, in the first chapter, she sees the host in procession and she falls in ecstasy (Vida $y$ fin, ff. $4 \mathrm{r}-4 \mathrm{v}$ ) and, in the second, the host is transfigured into a child (Vida y fin, ff. 6v). On the communion during Juana's abbacy, see (Graña Cid 2004, p. 320). 
continuously wearing" ("Y de que veýa muerta la candela, en el tiempo de las noches frías y largas del himbierno, para hazer mayor penitençia—junto con la ferviente oraçión — desnudávase en carnes delante de unas ymágenes, quedándosele el siliçio muy áspero, que contino traýa" (Vida y fin, f. 8r). First of all, it would be easy to relate Juana's nudity to Franciscan motifs that have their hagiographical origin in the codified images of the Francesco's denudation as a symbol of voluntary poverty. ${ }^{33}$ In particular, in Angela da Foligno's Liber, widely disseminated in the Iberian Peninsula at the time (Figure 1), there is a very famous passage where the Franciscan Tertiary takes off her clothes to embrace the crucifix (Angela da Foligno 1510, ff. $6 \mathrm{v}-7 \mathrm{r}$ ). The only problem is that in Angela's case, the process of the scene (she undresses and embraces the cross) does not refer specifically to an ascetic, contemplative prayer but rather to her renunciation of earthly goods to become a bride of Christ. Divergently, this divine marriage is configured in Vida y fin following once again in Caterina da Siena's footsteps: if in the Legenda maior Christ gives a diamond ring to Caterina at the end of her infancy (Vida f. XXXIIIr), in Juana's hagiography the child Jesus gives Juana a ring, through the mediation of the Virgin Mary (Vida y fin f. 26v). That this depiction of the child Juana as a naked ascetic derives from the Catherinian archetype more than a Franciscan source seems to be confirmed not only by texts but also by some scenes of Caterina da Siena as a penitent child that were iconographically codified in the 15th century (Hamburger 1998, pp. 463-65; Böse 2013, pp. 231-33; Figure 2).

Furthermore, this episode recalls the moment in the Legenda maior where the child Caterina, following the Fathers of the Desert, looks for solitude to discipline herself and soon finds a secret place in her house to do so (Vida f. IIv; IIIr). For her part, when Juana finally finds her own retreat (a walled dovecote in her aunt's house), she can finally perform this prayer in front of a veronica (Berónica):

And every time that she could, she went to that dovecote and put the veronica that she had brought on one side. And with some chains that she had previously hidden, she used to cruelly whip herself until she started to bleed, and she walked on her bare knees on rocks and stones until they hurt. And, full of tears and moaning, she walked this way as quickly as she could, considering that she was moving through the holy places and where our Lord Jesus Christ in his Passion was brought to be crucified, as when he was carrying the cross uphill, and that he looked at her with his merciful eyes.

Y todas las vezes que ella podía yba a aquel palomar y ponía la Berónica que traýa en una parte; y con unas cadenas que ella tenía allá escondidas, dávase muy crueles azotes, hasta que le salía sangre de sus carnes, y andava de ynojos, desnudas las rodillas sobre las grigeras y cantos, hasta que se le ollavan. ${ }^{34} Y$ con muchas lágrimas y gemidos andava desta manera con la más priesa que podía, considerando que yba por los lugares sanctos y por donde havían llevado a cruçificar a Nuestro Señor Jesuchristo apasionado, como quando llevava la Cuz a cuestas, y que la mirava con sus ojos de misericordia. (Vida y fin, f. $8 v$ )

33 Nudity is a very important topos of the Francesco's vitae: the two essential episodes are (Tommaso di Celano 2000) and (Bonaventura di Bagnoregio 2000, II: p. 4).

34 "Grigera" is not registered in the consulted dictionaries. In the electronic version of the Diccionario de la Real Academia Española, "grija" appears with the obsolete sense of "guijarro": https: / / dle.rae.es/grija (accessed on 1 January 2020). 


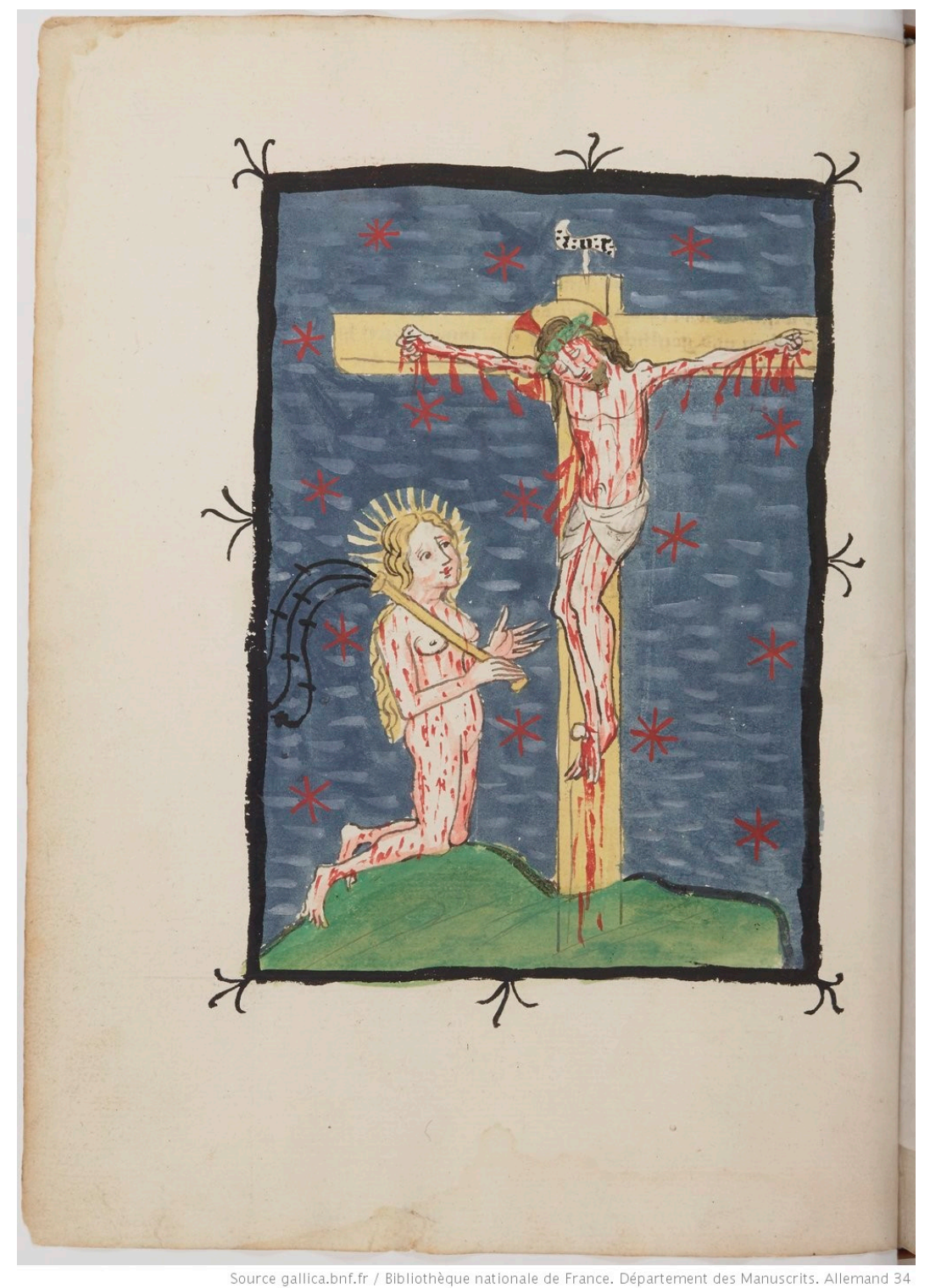

Figure 2. Caterina as a penitent child, the Geistliche Rosengarten, c. 1430; Paris, BnF, MS allemand 34, f. $4 \mathrm{v}$ (Source: gallica.bnf.fr/ BnF).

As the pioneering studies of Hamburger (1998, pp. 317-82) have shown, portable images produced massively like this veronica were common objects of devotion in Europe in the late Middle Ages. The fact that the child Juana was using hers to serve meditative purposes is specified in the third sentence of the fragment, where the verb considerar is used in its technical contemplative sense, from the Latin considerare (Mocan 2004). Without any doubt, here it signifies that the puella was using the image of the face of Christ to imagine a virtual pilgrimage through the main places and episodes of the Passion, keeping company with the suffering Christ, and finally embracing the compassio (Rudy 2011). The continuity between these disciplined performances involving images and those shown in Caterina da Siena's life simply form part, as has been said, of the continuity between late-medieval and early-modern devotion in Castile (Sanmartín Bastida 2012). This characteristic fills Juana's hagiography. Going back to her suffering in front of the crucifix:

She knelt tearfully facing a crucifix, pitying the sufferings of the Lord on the day of the Passion. [ ... ] And being with this compassion, suddenly she saw Our Lord Jesus Christ, or the image of the very passionate and wounded crucifix, and all the signs and mysteries of the Passion appeared, and the three Marys, all 
of them tearful and full of mourning. And so many mysteries and acts of the Holy Passion she saw and felt, and the crying was so much and her heart was pierced, that when the revelation (which she saw and heard bodily, being in her own senses and not raptured) finished, she seemed as if dead.

... yncose de ynojos delante un cruçifixo con muchas lágrimas, compadeçiéndose de lo qu'en tal día su Dios y Señor havía padeçido. [ . . . I Y estando con esta compasión, a deshora vido a Nuestro Señor Jesuchristo, o la ymagen de sancto crucifixo muy apasionado y llagado, y pareçieron allí todas las ynsignias e misterios de la Passión, y las tres Marías, todas muy llorosas y cubiertas de luto. Y tantos fueron los misterios e autos de la Sancta Passión que alli vido y sintió, y lo mucho que lloró e se traspasó su coraçón, que quando ya çesó de ver esta revelaçión, la qual vido e oyó corporalmente estando ella en sus propios sentidos e no estando arrovada, quedó tal que pareçía muerta ... (Vida y fin, ff. 8v-9r)

The framework of the scene is again the late-medieval model of contemplative prayer using the crucifix to envision the Passion (arma Christi included, Cooper and Denny-Brown 2014). As we can observe, Juana develops an ascetic model through which bodily penance and prayer could be followed by visionary phenomena. This fact is likely to refer to a continuity between medieval piety codified in hagiography and conventual performances in this specific community through exercises related to the imitatio Christi. The high number of these penitential passages that refer to seeking the compassio seem to point to the desire for recovering, re-enacting, or simply embracing this contemplative Christological tradition in the community. At this point, the question is whether those narrative scenes are merely simple developments of hagiographic themes or whether they point to a performance in a liturgical environment intra muros. Luckily, a passage kept in the Libro de la casa records similar practices performed by the nuns (Figure 3):

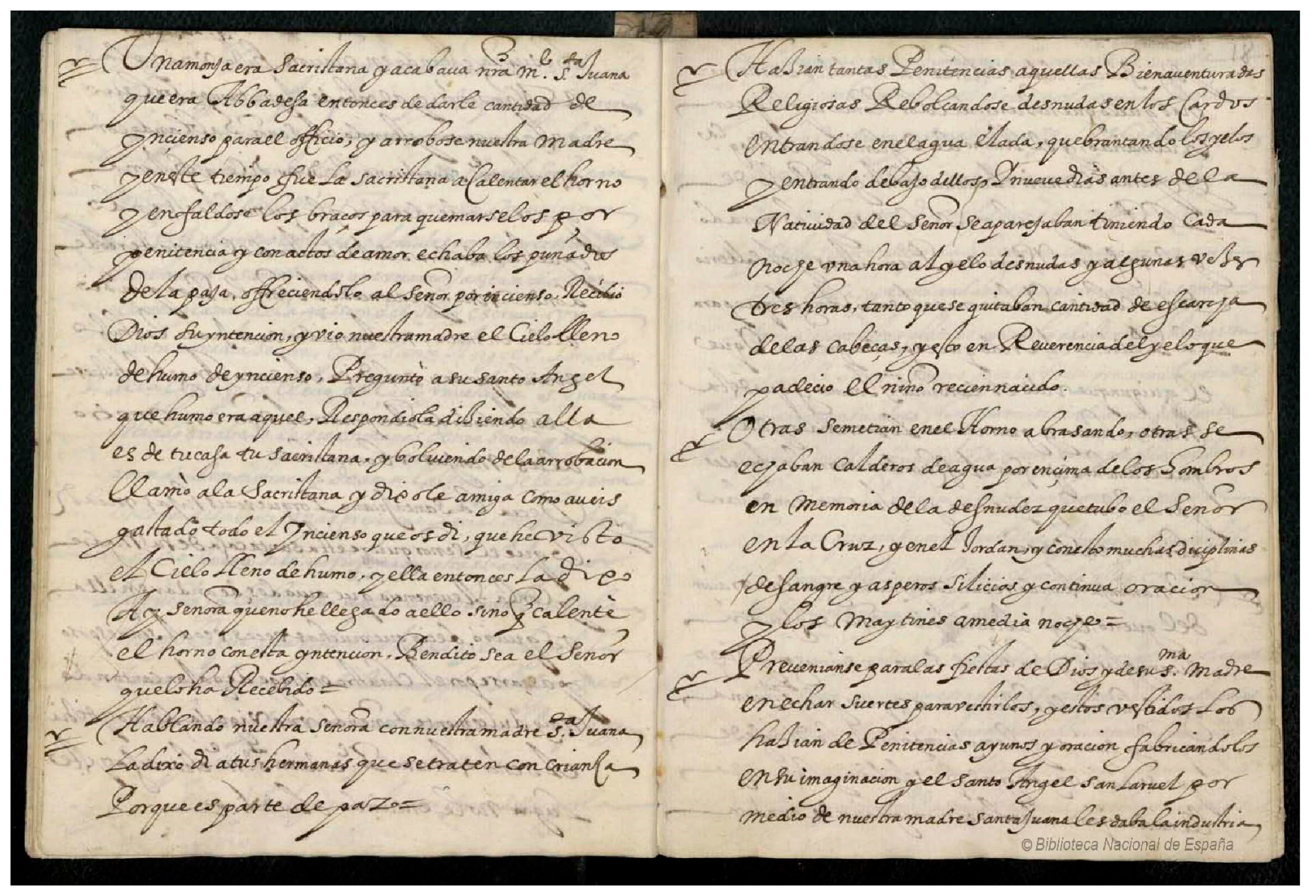

Figure 3. Libro de la casa, 17th century; Madrid, Biblioteca Nacional de España, MS 9661, ff. 17v-18r (Source: Biblioteca Digital Hispánica/ BNE. Imagen procedente de los fondos de la Biblioteca Nacional de España). 
Those blessed religious women used to do so many penances, rolling naked on thistles, bathing in frozen waters, breaking the ice and going under it. And nine days before the nativity of Our Lord, they used to prepare themselves by lying naked on the ice for one hour, and sometimes three hours, for so long that they had to remove the frost from their heads, and they used to do this in reverence of the Lord and of what the newborn Child suffered. // Other nuns used to put themselves inside the oven, burning themselves, others poured cauldrons of water on their shoulders in memory of the nakedness of the Lord hanging on the cross and in the river Jordan; and they used to do this with a lot of bloody disciplines and harsh cilices, and constant prayer and with matins at midnight. // They used to prepare themselves for the feasts of God and his holy Mother by drawing lots to wear them. And these clothes were made with penances, fasting, and payer, making them in their imagination.

Hazian tantas penitencias aquellas bienaventuradas religiosas, rebolcándose desnudas en los cardos, entrándose en el agua elada, quebrantando los yelos y entrando debajo d'ellos. Y nueve días antes de la natividad del Señor se aparejaban tiniendo cada noche una hora el yelo desnudas, y algunas vezes tres horas, tanto que se quitaban cantidad de escarcha de las cabezas; y esto en reverencia de Él y en lo que padeció el Niño recién nacido. // Otras se metían en el horno abrasando, otras se echaban calderos de agua por ençima de los hombros en memoria de la desnudez que tubo el Señor en la Cruz y en el Jordán; y con esto muchas disciplinas de sangre y ásperos silicios y continua oración y los maytines a media noche. // Preveníanse para las fiestas de Dios y de su santa Madre en echar suertes para vestirlos. Y estos vestidos los hazían de penitencias, ayunos y oración, fabricándolos en su imaginación [ . . . ]. (Curto 2018, f. 18r)

From my perspective, the most interesting feature of this fragment is the absolute performative dependence of the described penances on the liturgical calendar. As in the wider landscape of mendicant nunneries across Europe, liturgy needs to be perceived here as the basic principle of organization of the living knowledge of the community (Hamburger et al. 2016, p. 34). Not by chance, liturgical celebrations are the basic structure by which the visionary sermons of the Conhorte were pronounced, compiled, and ordered (Acosta-García Forthcoming). Here, the location of some of these commemorations in the yearly cycle ("nueve días antes de la natividad del Señor"; "las fiestas de Dios y de su santa Madre") allow us to understand the reference "in memory of the nakedness of the Lord hanging on the cross and in the river Jordan ("en memoria de la desnudez que tubo el Señor en la Cruz y en el Jordán") inserted into the liturgical time and also to check how the nuns, at the very least ideally, lived the imitatio Christi in a radical, corporeal manner. In this striking mixture of liturgy, extreme penance, and Christological devotion, the mental nature of the exercises performed by the nuns is highlighted, as in the previous fragment about a meditative considerare. As the anonymous author of the text declares in the final sentence of the quotation, they used to dress up for feasts of Christ and the Virgin Mary with "penance, fasting and oration" that were "made in their imagination". This places these practices (and, by extension, the images of the penitent Juana from Vida y fin) in the ambiguous terrain of representation. ${ }^{35}$

\subsection{Domingo, Francesco, and Chiara}

Self-mortification as an ideal way of life is synthetized in a sentence of Vida y fin which states that, from her very childhood, Juana "desired torments and wounds, ulcers, pains, cold and exhaustion" ("deseava tormentos e llagas, heridas, dolores, frío e cansancio", Vida y fin, f. 13v). This is because her hagiography represents her as an ideal penitent for (and in certain measure by) her historical Franciscan community. However, this ascetic

35 The question about whether these practices were merely imagined in meditation or whether they were actually performed does not have a simple answer and I cannot address it here, but the general framework of the Libro de la casa (a compiled aide-mémoire of a series of traditions of the convent with performative character) points in the direction that these practices actually used to take place during certain celebrations of the liturgical cycle. 
character is formalized following a model - that of the mantellata Caterina da Siena, who was also a mendicant penitent, but a Dominican one. In fact, there does not appear to be anything exclusively Franciscan in the way in which Juana's infancy is presented. It could be argued that while her most radical trait of maturity-the stigmatization-is preceded by Francesco d'Assisi's reception of the holy wounds, it could also have been mediated by Caterina da Siena's experiences (Acosta-García 2021). Therefore, it is necessary to raise essential questions about group identity here: could the recognizable model of Caterina cause conflicts in the textual community to which this narration was ultimately addressed? Does Juana's hagiography distance itself from the other mendicant orders? If so, in what ways does it achieve this? In this final subsection, I will briefly address some passages dealing with the wider conflict of the mendicant-penitent identity.

The importance of Francesco d'Assisi is highlighted from the beginning of the book and there is a general tendency to identify the community with his figure more with than anyone else, even Chiara d'Assisi. ${ }^{36}$ In fact, Vida $y$ fin is paved with narratives integrated in the clash between Franciscans and Dominicans. This fact suggests that Juana's community needed to vindicate its Franciscan roots through the textually recreated figure of their abbess. The first reference to the two orders is found in the section that narrates Juana's childhood. In addition to the rich aunt who took care of her, she had another one: a nun in the Dominican Convent of Santo Domingo el Real (Toledo). Along with her sisters in the order, she tries to attract Juana to the Dominican life in the time before the latter decides to enter the Convent of Santa María de la Cruz:

And in all this time they did not cease from begging Our Lord, his Divine Majesty, to allow them to bring to their order that most precious treasure and holy creature. And they could never achieve this because God had not raised her for the Dominicans but for the restauration of the house of the Queen of Heaven, for whose pleas she was raised.

Y en todo este tiempo no cesavan de suplicar a Nuestro Señor, su Divina Magestad, permitiese de traer a su orden aquel tan preçioso thesoro y criatura tan sancta. Y nunca la pudieron alcançar, por quanto no la havía criado Dios para ellas, sino para el reparo de la casa de la Reyna de los Çielos, por cuyos ruegos fue criada. (Vida y fin, f. 6r)

Of course, the narrator's main argument against the Dominican possibility is based on grace. God wanted Juana for the Franciscan convent for a strong reason: to be the reformer of the religious house ("para el reparo de la casa"). On the other hand, it is worth noting that Santo Domingo el Real in Toledo is linked to the biography of the controversial María de Santo Domingo, a Dominican Tertiary who was also a reformer, a stigmatic, and a charismatic preacher (Bilinkoff 1996). ${ }^{37}$ According to Beltrán de Heredia ([1937] 1939, pp. 79-80), María visited this monastery in 1507 to "promote the observance there" ("promover alli la observancia"). ${ }^{38}$ The existence of a Dominican reformer supported by Cisneros, also showing Catherinian features in the narratives about her life (Sanmartín Bastida 2012, pp. 320-24, 332) - especially the stigmata and a performative prophetical activity-could have motivated this remark about Juana's belonging to the Franciscan order, highlighting her link with a specific convent. Furthermore, it is necessary to remember that a sentence such as this one was inserted at the beginning of the book, justifying her succeeding Inés as leader of the convent. This fact reinforces the idea of Vida $y$ fin as a defense of the renewed life of the community of Cubas de la Sagra from the perspective of Juana's abbacy and, therefore, the Cisnerian reform.

\footnotetext{
36 In fact, the founder of the Second Order of Saint Francis appears just two times in the whole narration: the first one, her name is written twice in order to fix a date (f. 75v); the second one, in a vision, in the last position of a list of saints that includes Caterina, Cecile, and Barbara. From my perspective, this apparent indifference towards Chiara may be because of that penitential character which continues to define the community even after its institutionalization and the adoption of the enclosure.

37 For the edition of the works related to María, see (Sanmartín Bastida and Balbás 2014) and (Sanmartín Bastida and Hernández 2019).

38 I thank Mercedes Pérez Vidal for indicating this relationship to me, and Rebeca Sanmartín Bastida for the exact reference.
} 
This first attempt to integrate Juana into the Dominicans continues later in the book. In chapter fourteen, in the middle of a series of revelations received during her abbacy, Juana sees how Francesco d'Assisi and Domingo de Guzman come close to her and start a lively conversation, reminiscent of the theatrical setting of the visionary sermons of the Conhorte. Domingo de Guzmán's main argument is that Juana belongs to his order, referring to the aforementioned episode when her Dominican aunt tried to attract her to the convent in Toledo. The argument is, therefore, based on the right of precedence: "She is my daughter by right, and not yours, because she was first called to my order and desired by my nuns, and also by my friars, and sought with so much care" ("es mi hija por derecho, y no vuestra, pues fue primero llamada a mi orden y desseada de mis monjas, y aun también de mis frayles, $y$ buscada con arto cuidado" (Vida y fin, f. 76r). The discussion continues in this fashion and, finally, they ask Juana herself to choose between the two orders, making her decide between two symbolic habits. Of course, she choses the Franciscan one, but I am especially interested in her reasons:

"We want to show you our habits, to ascertain which one you like more." And he showed me his habit, so very white and pure, signifying the sanctity and purity of Our Lady the Virgin Mary, Mother of God. And our blessed father Saint Francis showed me his habit, humble, poor, and bloody, which signifies the sacred Passion and the wounds of Our Lord Jesus Christ, which Jesus Christ himself had given to him. I answered: "The habit that I like and which I desire is that which is dyed with the Passion and the wounds of my Lord Jesus Christ."

"Queremos te mostrar nuestros ábitos, a ver de quál te agradas más". E mostrome el suyo, muy blanco y puro, que significava la sanctidad y limpieza de Nuestra Señora la Virgen María, Madre de Dios. E nuestro bienabenturado padre sant Francisco mostrome el suyo, humilde, y pobre e sangriento, que significa la sagrada Passión e llagas de Nuestro Señor Jesuchristo, las quales havía el mesmo Christo, Señor mío, transformado en Él. Respondí: "El que más me agrada y quiero de estos sanctos ábitos es el que está teñido en la Pasión e llagas de mi señor Jesuchristo". (Vida y fin, f. 77r)

As the text asserts, the Dominican habit here personifies the Virgin Mary through her purity, while the Franciscan one does the same with Francis through his suffering. It could seem strange that the abbess of a convent founded by the mediation of the Virgin Mary and dedicated to her should so directly disregard a garment that represents her attributes, but the intention of the passage is clearly to define Juana as a Franciscan. From the collective point of view implicit in Vida y fin, the community of the Convent of Santa María de la Cruz seems to be defending here an essentially Franciscan penitential identity based on self-suffering and seeking the compassio. In this respect, despite the paradoxical fact that the Dominican Caterina's vita forms the basic structure of Vida $y$ fin, the passages that I have analyzed in the previous subsection about "torments and ulcers, wounds, pains, cold and exhaustion" ("tormentos e llagas, heridas, dolores, frío e cansancio") need to be contextually understood as a part of a Franciscan way of life based on the imitatio Christi in a convent with an eminently Christocentric devotion. At least from the text's perspective, those painful exercises analyzed above are clearly seen as part of their Franciscan tradition and, therefore, the imitatio Christi is perceived to a large extent also as an imitatio Francisci (Herzig 2013).

This is the reason why the climax of this extreme bodily discipline-the authentic Christification-arrives in Juana's maturity with her reception of the stigmata. First, it is necessary to understand Juana in the context of the sante vive (Zarri 1980, 1990, 2010). The 15th-century phenomenon of charismatic religious women acquiring the authority to preach, prophesy, and receive revelations in front of influential courtly audiences was contemporaneous in both the Italian Peninsula and Castile. The performative character of these raptures gives a real interest to every bodily phenomenon that could confirm the holiness of the living saint. During Cardinal Cisneros' times, the stigmatization of Lucia da Narni was promoted in the form of a printed pamphlet (Bilinkoff 1992; Herzig 2008, pp. 106-9) 
and in the Cardinal's closest circles there are records of three other stigmatic women: María de Ajofrín, María de Santo Domingo, and Juana de la Cruz herself (Acosta-García 2021). As I have addressed elsewhere, a defining trait of these three Castilian charismatic religious women is that they did not have the ambiguity of Caterina da Siena's invisible stigmatatheir marks were clearly visible and touchable, although in Juana's case they were not bloody. In Vida y fin, the wounds are described as: "some round signs, the size of a coin, and very red-colored, in a way that they seem printed on the upper part of the palms of her hands, and a similar thing on the soles of her feet" (= "unas señales redondas, del tamaño de un real, y muy coloradas, de manera que parecían por las palmas de las manos que estaban impresas por la parte de encima, y por semejante parecía en las plantas de los pies", Vida y fin, f. 38v). Although Juana's wounds finally disappear after her request to Christ (a fact which places her once again as following the footsteps of Caterina and Lucia da Narni (Zarri 1990, pp. 51-57), their initial visibility signifies overcoming the Catherinian model of the invisible stigmata established by Raimondo da Capua and, by extension, overcoming the original Dominican model of feminine sanctity. In short, as with the Franciscan Observant abbess Chiara Bugni, a contemporary reformed Franciscan abbess in Venice (Zarri 2011, p. XXIV), the stigmata in Juana's flesh signify her absolute closeness to Francesco's experience: “Ora Chiara [or, in this case, Juana] è diventata non solo un alter Christus, ma anche un secondo Francesco, come lui insignita delle stigmate."

As a matter of a fact, the founder of the order is omnipresent in Vida $y$ fin. His presence is highlighted in the visions of chapter XXII and, at the level of hagiographical themes, there are very clear references to his own vitae. For instance, in (Vida y fin f. 31r), an episode that takes place before Juana's abbacy is described. She has started to preach ecstatically with the prophetic voice that will make her famous, but in these early times this had been prohibited by her superiors. She is confined to her private cell and the abbess sends a sister to check on her:

And when she went there, she saw how the Lord was still speaking, and the floor of the cell was full of many different birds, and they were all quiet and paying attention, hearing the word of God, and most of them were very close to her and all around her bed, and they were like this until the Lord had finished speaking and had given the blessing, as on other occasions he was accustomed to doing.

E yendo, vido cómo aún el Señor todavía hablaba, y el suelo de la çelda estava lleno de muchas maneras de aves volantías, e todas muy atentas y quietas, escuchando la palabra de Dios, e las más e todas estavan muy çercanas a ella y alrededor de su cama, y assí estuvieron hasta que el Señor huvo acavado de hablar e dado la bendiçión, según otras veçes ascostumbrava haçer. (Vida y fin, f. 31r)

The reference to the episode of Francesco's preaching to the birds is clear and serves to reinforce the authority of Juana's prophetic voice by equating her in this way with the founder of the order, especially when this is compared with a previous experience from her infancy. ${ }^{39}$ The first reference to this "language of the birds" appears in its first chapter (Vida y fin, f. 4r), when the child Juana has a vision in which she sees a divine garden where beautiful children are singing to the birds and the birds are singing back to them. This seems to refer to the episode narrated in Bonaventura di Bagnoregio (2000, VIII: p. 9) and it indicates the impossibility of the child's achieving divine comprehension and, by extension, to be able to use the powerful enraptured discourse that will come later. At this point, she is not able to talk or understand that language, but she will. On the other side, fighting against the ambiguity of the images of nudity mentioned in the previous subsection, an episode during Juana's maturity definitively links the denudatio with a Franciscan model found in El floreto del glorioso padre San Françisco (Ulibarrena 1998) and with the idea of detachment from sins via extreme bodily penance (Vida y fin f. 15r). In this respect, the accepted Catherinian infancy becomes a disciplined and explicitly Franciscan maturity.

39 The episode of the preaching to the birds is in (Tommaso di Celano 2000, XXI: p. 58). 


\section{Conclusions}

Vida y fin is a collective account of the Convent of Santa María de la Cruz in various respects. Although there is no documentary evidence that proves that it was composed by several nuns, the text clearly expresses the history of the community from its own perspective. This is suggested by passages that I have analyzed which make difficult to deny the role of Juana's hagiography as a chronicle of the community. First, the account about the foundation of the convent includes indications that allow us to talk about a collectivity which is conscious of its own roots and of the significance that the reform had in its members' lives. In the middle of this landscape, the figure of Juana de la Cruz, the charismatic abbess who undertook the reform process, is presented as a real agent. She was ultimately called by Christ (through the mediation of his mother) to succeed Inés as a radical, visionary, prophet, and leader of the community. Her destiny as a reformer is textually codified, while her authority to do so is expressed even before her birth through the androgynous attributes given to her in her mother's womb. The child Juana is a leader and an exemplar, as she incarnates the innate, original virtuous behavior which the community had lost. Her clothes, her fasting, her silence, and her bodily penitence are a model to correct the present state of the community.

In this sense, in the context of the reform undertaken by Cardinal Cisneros following the orders of the Catholic Monarchs, this desirable set of characteristics is related to the Observant view of religious life. This ideal is clearly codified in the rules, especially in those closer to the founder's legacy that the Cardinal sent to the printing presses. The contradiction is that, at the same time that he was promoting a return to the Franciscan origins of poverty, the convents he was reforming were being turned into enclosed ones (and, in Juana's case, a cloistered community that received rents). This inconsistency could be related to a cardinal who thought and acted dichotomously: on the one hand, following the Observant ideals, promoting Christocentric devotion related to mystical phenomena, and supporting charismatic women as reformers; on the other hand, backing the policies of the Catholic Monarchs, which implied institutionalization, regularization, and control. In this respect, the Franciscan rules dialogue with the behavioral models codified in the hagiographies, not only with Vida y fin but also with its late-medieval models that were reintegrated during that period. I have tried to show that Triviño's view of the adopted rule of the Convent of Santa María after 1464 agrees not only with the general tendencies of reforming Franciscan Tertiaries in the area of Toledo, but also with some information found in Juana's vita. If Juana's convent was in effect following a variation of the Urbanist rule in the form of some Constitutions, it is also true that the way of life defended in Vida $y$ fin is more a continuous calling back to the origins of the penitential order rather than a mitigated rule for enclosed, contemplative nuns. In fact, enclosure is mentioned only at the incipit of the account, while self-mortification permeates it.

These late-medieval Christocentric devotions related to mystical phenomenology were supported by Cardinal Cisneros' Observant reform and were codified in the chapters of the primary rules of the order and elsewhere. The most ascetic traits about self-mortification are highlighted in the lives of late-medieval saints, especially in Raimondo da Capua's Legenda maior of Caterina da Siena. But biography always exceeds hagiography. The mantellata's childhood, as accounted by Raimondo, provides a strong structure that combines parts of Juana's life with motifs related to extreme penance and the imitatio Christi. As we have seen, the text found strategies to present the fact that Caterina was a Dominican rather than a Franciscan penitent as being far from problematic: the account focuses on the penitential traits of the child and mobilizes textual resources to settle a fundamentally penitential identity textually perceived as Franciscan. In fact, the combination of innate virtuous behavior and the imitatio Christi leads to an explicit Christification, similar to that of Francesco, which goes beyond Caterina's experience as narrated in Raimondo da Capua's Legenda maior. This is a common trait of the three Castilian stigmatic women, but in Juana's live Christ is always presented as the ideal point of arrival. 
To sum up, Vida y fin expresses a series of tensions in the life of the community of the abbess Juana de la Cruz shortly after her death. The nuns seem to pursue an identity dealing with ideas originally incarnated by the founders of the orders and then reincarnated in their prophetic abbess. The continuity of the patterns of medieval piety, especially the seeking of an extreme compassio, seem to be at the core of a surviving culture of a newly enclosed community of Franciscan Tertiaries.

Funding: This article has received funding from the European Union's Horizon 2020 research and innovation program under the Marie Skłodowska-Curie grant agreement No. 842094.

Acknowledgments: I want to thank Eva Schlotheuber, Victoria Cirlot, Rebeca Sanmartín Bastida, María del Mar Graña Cid, Jessica A. Boon, Mercédes Pérez Vidal, Sergi Sancho Fibla, and María Victoria Triviño for their generous comments on Juana de la Cruz, which helped me to enhance the quality of this article. Also I would like to thank the rest of the members of the research project 'Catálogo de santas vivas (1400-1550): hacia un corpus completo de un modelo hagiográfico femenino' (PID2019-104237GB-I00) for their great support in discussing the contents of the article. Finally, I thank the two anonymous peer reviewers, whose comments helped to improve the quality of this text.

Conflicts of Interest: The author declares no conflict of interest.

\section{References}

\section{Primary Sources}

Angela da Foligno [de Fulginio]. 1055. Liber qui dicitur Angela de Fulginio: in quo ostenditur nobis vera via qua possumus sequi vestigia nostri redemptoris. Toleti: [sucesor de Pedro Hagenbach] iussu Francisci Ximenez archiepiscopi, 18 Aprilis "1055" [= 1505].

Angela da Foligno [de Fulgino]. 1510. Libro dela bienavēturada sancta Angela de Fulgino: enel qual se nos muestra la verdadera carrera pa seguir las pisadas de nuestro redēptor y maestro Jesu Christo. Itē Primera regla ðla bienavèturada virgē santa Clara. Itē Tractado del bienavēturado sant Vincēte dela vida 7 instrucion espiritual que deven tener los religiosos 7 psonas devotas. Toledo: [sucesor de Pedro Hagenbach] por mandado de fray Francisco Ximenez, 24 mayo 1510.

Bonaventura di Bagnoregio. 2000. Leyenda mayor. In San Francisco de Asís. Escritos y biografías. Documentos de la época. Edited by José Antonio Guerra. Madrid: BAC, pp. 380-500.

Boon, Jessica, and Ronald E. Surtz. 2016. Mother Juana de la Cruz, 1481-1534: Visionary Sermons. Translated by Ronald E. Surtz and Nora Weinerth. Toronto and Tempe: Iter Academic Press-Arizona Center for Medieval and Renaissance Studies.

Curto, María Victoria. 2018. Libro de la Casa y Monasterio de Nuestra Señora de la Cruz. In Catálogo de santas vivas. Edited by María Victoria Curto. Available online: http://catalogodesantasvivas.visionarias.es/index.php/Juana_de_la_Cruz (accessed on 8 September 2020).

Esser, Kajetan. 2013. François d'Assise. Écrits. Introduction, translation, and notes by Théophile Desbonnets, Jean-François Goddet, Thaddée Matura, and Damien Vorreux. Paris: Les Éditions du Cerf-Les Éditions Franciscainies.

Luengo Balbás, María, and Fructuoso Atencia Requena. 2019. Vida y fin de la bienaventurada virgen sancta Juana de la Cruz, monja que fue professa de quatro botos en la orden del señor sant Francisco, en la qual vivió perfeta y sanctamente. Edited by María Luengo Balbás and Fructuoso Atencia Requena. In Catálogo de santas vivas. Available online: http://catalogodesantasvivas. visionarias.es/index.php/Juana_de_la_Cruz (accessed on 8 September 2020).

Navarro, Pedro. 1659. Favores de el Rey del cielo, Hechos a sv esposa la Sania Jvana de la Cruz, Religiosa de la Orden tercera de Penitencia de N. P. S. Francisco: con anotaciones theologicas y morales, a la historia de su vida. Madrid: Mateo Fernandez Impresor del Rey. First published 1622.

Omaechevarría, Ignacio, ed. 2015. Escritos de Santa Clara y documentos complementarios. Edición bilingüe. Madrid: BAC. First published 1970.

Pedro de Salazar. 1977. Coronica y historia de la fundacion y progresso de la Provincia de Castilla, de la Orden del bienauenturado padre San Francisco. Madrid: Imprenta Real. [facsimile: Crónicas franciscanas de España, vol. 6. Prologued and indexed by Antolín Abad Pérez. Madrid: Editorial Cisneros, 1977]. First published 1612.

Raymundo de Capua [Raimondo da Capua]. 1511. La vida de la bien aventurada sancta Caterina de Sena trasladada de latin en castellano. Y la vida dela bien aventurada soror Joana de orbieto: y de soror Margarita de Castello. Translated by Antonio de la Peña. Alcalá de Henares: Arnao Guillen de Brocar.

Sanmartín Bastida, Rebeca, and María Victoria Curto Hernández. 2019. El Libro de la oración de María de Santo Domingo. Estudio y edición. Madrid and Frankfurt am Main: Iberoamericana-Vervuert.

Sanmartín Bastida, Rebeca, and María Luengo Balbás. 2014. Las Revelaciones de María de Santo Domingo (1480/86-1524). London: Department of Iberian and Latin American Studies (Queen Mary, University of London).

Svaraglia, Giovanni Giacinto [Joannis Hyacinthi Sbaraleae]. 1759-1788. Bullarium franciscanum romanorum pontificium: constitutiones, epistolas, ac diplomata continens: tribus ordinibus Minorum, Clarissarum, et Poenitentium a seraphico patriarcha Sancto Francisco institutis concessa: ab illorum exordio ad nostra usque tempora. Romae: Typis Sacrae Congregationis de Propaganda Fide, 4 vols. 
Tommaso di Celano. 2000. Vida Primera. In San Francisco de Asís. Escritos y biografías. Documentos de la época. Edited by José Antonio Guerra. Madrid: BAC, pp. 140-230.

\section{Secondary Sources}

Abad Pérez, Antolín. 1968. San Juan de la Penitencia, obra social del Cardenal Cisneros en Toledo. Anales Toledanos 2: 1-88.

Acosta-García, Pablo. 2020a. On Manuscripts, Prints and Blessed Transformations: Caterina da Siena's Legenda maior as a Model of Sainthood in Premodern Castile. Religions 11: 33. [CrossRef]

Acosta-García, Pablo. 2020b. Santas y marcadas: itinerarios de lectura modélicos en la obra de las místicas bajomedievales impresas por Cisneros. Hispania Sacra LXXII: 67-80. [CrossRef]

Acosta-García, Pablo. 2020c. Women Prophets for a New World: Angela of Foligno, 'Living Saints', and the Religious Reform Movement in Cardinal Cisneros' Castile. In Exemplarity and Gender in Medieval and Early Modern Iberia. Edited by Maria Morrás, Rebeca Sanmartín and Yonsoo Kim. Leiden: Brill, pp. 136-62. [CrossRef]

Acosta-García, Pablo. 2021. “En viva sangre bañadas": Caterina da Siena y las vidas de María de Ajofrín, Juana de la Cruz, María de Santo Domingo y otras santas vivas castellanas. Archivio Italiano per la Storia della Pietà XXXIII: 143-72. [CrossRef]

Acosta-García, Pablo. Forthcoming. Liturgy and Revelation in the Book of the Conhorte by the Abbess Juana de la Cruz (1481-1534). Leiden: Brill.

Ahlgren, Gillian T. W. 2000. Ecstasy, Prophecy, and Reform: Catherine of Siena as a Model for Holy Women of Sixteenth Century Spain. In The Mystical Gesture. Essays on Medieval and Early Modern Spiritual Culture in Honor of Mary E. Giles. Edited by Robert Boenig. Aldershot: Ashgate, pp. 53-65.

Matter, Ann E., and Gabriella Zarri. 2011. Una mistica contestata. La Vita di Lucia da Narni (1476-1544) tra agiografia e autobiografia. Roma: Edizioni di Storia e Letteratura.

Bataillon, Marcel. 1996. Erasmo y España. Mexico: FCE. First published 1937.

Beltrán de Heredia, Vicente. 1939. Historia de la reforma de la Provincia de España (1450-1550). Rome: Institutum historicum F. F. Praedicatorum. First published 1937.

Bilinkoff, Jodi. 1992. A Spanish Prophetess and Her Patrons: The Case of María de Santo Domingo. Sixteenth Century Journal 23: 21-34. [CrossRef]

Bilinkoff, Jody. 1996. Charisma and Controversy: The case of María de Santo Domingo. In Spanish Women in the Golden Age: Images and Realities. Edited by Magdalena S. Sánchez and Alain Saint-Saëns. Westport and London: Greenwood Press, pp. 23-35.

Boon, Jessica A. 2016. Introduction. In Mother Juana de la Cruz, 1481-1534: Visionary Sermons. Edited by Jessica A. Boon and Ronald E. Surtz. Translated by Ronald E. Surtz and Nora Weinerth. Toronto and Tempe: Iter Academic Press-Arizona Center for Medieval and Renaissance Studies, pp. 1-33.

Boon, Jessica A. 2018. At the Limits of (Trans) Gender: Jesus, Mary, and the Angels in the Visionary Sermons of Juana de la Cruz (1481-1534). Journal of Medieval and Early Modern Studies 48: 261-300. [CrossRef]

Böse, Kristin. 2013. 'Uff daz man daz unsicher von dem sichren bekenen mug'. The Evidence of Visions in the Illustrated Vitae of Catherine of Siena. In Catherine of Siena. The Creation of a Cult. Edited by Jeffrey F. Hamburger and Gabriella Signori. Turnhout: Brepols, pp. 215-238.

Braguier, Laurey. 2019. Servantes de Dieu. Les beatas de la Couronne de Castille (1450-1600). Rennes: Presses Universitaires de Rennes.

Bynum, Carolyne Walker. 1987. Holy Feast and Holy Fast: The Religious Significance of Food to Medieval Women. Berkeley, Los Angeles and London: University of California Press.

Cátedra, Pedro. 2005. Liturgia, poesía y teatro en la Edad Media. Estudios sobre prácticas culturales y literarias. Madrid: Gredos.

Cirlot, Victoria, and Blanca Garí. 2008. La mirada interior. Madrid: Siruela.

Cooper, Lisa H., and Andrea Denny-Brown. 2014. The Arma Christi in Medieval and Early Modern Material Culture: With a Critical Edition of 'O Vernicle'. Franham: Ashgate.

García de Andrés, Inocente. 1999. El Conhorte: Sermones de Una Mujer. La Santa Juana (1481-1534). Madrid: Fundación Universitaria Española-Universidad Pontificia de Salamanca, 2 vols.

García Oro, José. 1971. Cisneros y la reforma del clero español en tiempo de los Reyes Católicos. Madrid: CSIC.

García Oro, José. 1980. Conventualismo y observancia. La reforma de las órdenes religiosas en los siglos XV y XVI. In Historia de la Iglesia en España. Edited by Ricardo García-Villoslada. Madrid: La Editorial Católica, vol. 3.1, pp. 211-350.

García Oro, José. 2005. Reforma y reformas en la familia franciscana del Renacimiento. Cuadro histórico del tema. In El franciscanismo en la Península Ibérica. Balance y Perspectivas: I Congreso Internacional, Madrid, 22-27 de septiembre de 2003. Edited by María del Mar Graña Cid and Agustín Boadas Llavat. Barcelona: CBG Editora, pp. 235-53.

Gómez López, Jesús. 2004. Juana de la Cruz (1481-1534) 'La Santa Juana': Vida, obra, santidad y causa. In La clausura femenina en España: actas del simposium: 1/4-IX-2004. Edited by Francisco Javier Campos y Fernández de Sevilla. Madrid: Real Centro Universitario Escorial-María Cristina, vol. 2, pp. 1223-50.

Graña Cid, María del Mar. 1994a. Las primeras clarisas andaluzas. Franciscanismo femenino y reconquista en el siglo XIII. Supplement of Archivo Ibero-Americano LIV: 661-704.

Graña Cid, María del Mar. 1994b. Mujeres y educación en la Prerreforma castellana: los colegios de doncellas. In Las sabias mujeres: educación, saber y autoría (siglos III-XVII). Edited by María del Mar Graña Cid. Madrid: Al-Mundayna, pp. 117-46. 
Graña Cid, María del Mar. 1998. Apostolado femenino, clausura y santidad: la obra de Angelina de Montegiove (ca. 1357-1435). In Mujeres que se atrevieron. Edited by Isabel Gómez Acebo. Bilbao: Desclée de Brouwer, pp. 157-200.

Graña Cid, María del Mar. 2004. El cuerpo femenino y la dignidad sacerdotal de las mujeres. Claves de autoconciencia feminista en la experiencia mística de Juana de la Cruz (1481-1534). In Umbra, Imago, Veritas. Homenaje a los profesores Manuel Gesteira, Eusebio Gil y Antonio Vargas Machuca. Edited by Secundino Castro Sánchez, Fernando Millán Romeral and Pedro Rodriguez. Madrid: Universidad Pontificia de Comillas, pp. 305-36.

Graña Cid, María del Mar. 2008. Espacios de vida espiritual de mujeres (Obispado de Córdoba, 1260-1550). Ph.D. thesis, Universidad Complutense de Madrid, Madrid, Spain.

Graña Cid, María del Mar. 2009. La feminidad de Jesucristo y sus implicaciones eclesiales en la predicación mística de Juana de la Cruz (Sobre la Prerreforma y la Querella de las Mujeres en Castilla). Estudios eclesiásticos: Revista de investigación e información teológica y canónica 84: 477-513.

Graña Cid, María del Mar. 2017. Las profetisas ante el poder eclesiástico: denuncia y modelo místico de iglesia (Juana de la Cruz, siglo XVI). In Género e interioridade na vida religiosa. Conceitos, contextos e práticas. Edited by João Luís Fontes, Maria Filomena Andrade and Tiago Pires Marques. Lisboa: Centro de estudios de História Religiosa-Universidade Católica Portuguesa, pp. 15-44.

Graña Cid, María del Mar. 2018. Vivir la vida celestial: Caridad y acción social en beguinas y beatas (siglos XIII-XV). Estudios Eclesiásticos 93: 511-50.

Hamburger, Jeffrey F. 1998. The Visual and the Visionary. New York: Zone Books.

Hamburger, Jeffrey, Eva Schlotheuber, Susan Marti, and Margot Fassler. 2016. Liturgical Life and Latin Learning at Paradies bei Soest (1300-1425). Münster: Aschendorff Verlag.

Herzig, Tamar. 2008. Savonarola's Women. Visions and Reform in Renaissance Italy. Chicago: Chicago University Press.

Herzig, Tamar. 2013. Stigmatized Holy Women as Female Christs. Archivio italiano per la storia della pietà XXVI: 151-75.

Hubrath, Margarete. 1999. The 'Liber specialis gratiae' as a Collective work of Several Nuns. Jahrbuch der Oswald von WolkensteinGesellschaft 11: 233-44.

Huerga, Álvaro. 1968. Santa Catalina de Siena en la historia de la espiritualidad hispana. Teología Espiritual XII: 165-228.

Luongo, Thomas F. 2013. Saintly Authorship in the Italian Renaissance: The Quattrocento Reception of Catherine of Siena's Letters. In Catherine of Siena: The Creation of a Cult. Edited by Jeffrey F. Hamburger and Gabriela Signori. Turnhout: Brepols, pp. 135-68.

McGinn, Bernard. 2017. Mysticism in the Golden Age of Spain (1500-1650). Part 2. New York: Crossroad.

Mixon, James. 2015. Observant Reform's Conceptual Frameworks between Principle and Practice. In A Companion to the Observant Reform in the Late Middle Ages and Beyond. Edited by James D. Mixon and Bert Roest. Leiden: Brill, pp. 60-84.

Mocan, Mira. 2004. I pensieri del cuore. Per la semantica del provenzale cossirar. Roma: Bagatto Libri.

Mooney, Catherine M. 2013. Wondrous Words: Catherine of Siena's Miracolous Reading and Writing According to the Early Sources. In Catherine of Siena: The Creation of a Cult. Edited by Jeffrey F. Hamburger and Gabriela Signori. Turnhout: Brepols, pp. 263-90.

More, Alison. 2015. Dynamics of Regulation, Innovation and Invention. In A Companion to the Observant Reform in the Late Middle Ages and Beyond. Edited by James D. Mixon and Bert Roest. Leiden: Brill, pp. 60-84.

Muñoz Fernández, Ángela. 1994. Santas y beatas neocastellanas: Ambivalencias de la religión y políticas correctoras del poder. Madrid: Comunidad de Madrid, Dirección General de la Mujer.

Muñoz Fernández, Ángela. 1998. Mujer y experiencia religiosa en el marco de la santidad medieval. Madrid: Al-Mundayna.

Muñoz Fernández, Ángela. 2016. Iberian Women in Religion and Policies of Discipline Dissent in the Archbishopric of Toledo in the 15th to Early 16th centuries: The Heaven of Juana de la Cruz. In Strategies of Non-Confrontational Protest in Europe from the Twelfth to the Early Sixteenth Century. Edited by Fabrizio Titone. Roma: Viella, pp. 195-217.

Omaechevarría, Ignacio. 1972. Las clarisas a través de los siglos. Madrid: Cisneros.

Pérez Vidal, Mercedes. 2015. La reforma de los monasterios de dominicas en Castilla: Agentes, etapas y consecuencias. Archivo Dominicano XXXVI: 197-237.

Pérez Vidal, Mercedes. 2021. Female Aristocratic Networks: Books, Liturgy and Reform in Castilian Nunneries. In Relations of Power. Women's Networks in the Middle Ages. Edited by Emma O. Bérat, Rebecca Hardie and Irina Dumitrescu. Göttingen: Bonn University Press-V\&R University Press, pp. 105-32.

Redondo, Valentín. 2005. La historia de los franciscanos conventuales, ayer y hoy. In El Franciscanismo en la Península Ibérica. Balance y perspectivas: I Congreso Internacional, Madrid, 22-27 de septiembre de 2003. Edited by María del Mar Graña Cid and Agustín Boadas Llavat. Barcelona: CBG Editora, pp. 273-96.

Rudy, Kathryn M. 2011. Virtual Pilgrimages in the Convent. Imagining Jerusalem in the Late Middle Ages. Turnhout: Brepols.

Sancho Fibla, Sergi. Forthcoming. Reading in community, writing a community. Douceline's Vida and the beguines of Roubaud. In Transgression, Exclusion and Persecution in the Middle Ages. Edited by Delfi Nieto-Isabel and Laura Miquel Millan. Berlin: DeGruyter.

Sanmartín Bastida, Rebeca. 2012. La representación de las místicas. Sor María de Santo Domingo en su contexto europeo. Santander: Real Sociedad Menéndez Pelayo.

Sanmartín Bastida, Rebeca. 2013. La construcción de la santidad en María de Santo Domingo: la imitación de Catalina de Siena. Ciencia Tomista 140: 141-59.

Sanmartín Bastida, Rebeca. 2015. La comida visionaria: formas de alimentación en el discurso carismático femenino del siglo XVI. London: Splash. 
Surtz, Ronald E. 1990. The Guitar of God. Gender, Power, and Authoritity in the Visionary World of Mother Juana de la Cruz (1481-1534). Philadelphia: University of Pennsylvania Press.

Surtz, Ronald E. 1995. Writing Women in Late Medieval and Early Modern Spain: The Mothers of Saint Teresa of Avila. Philadelphia: University of Pennsylvania Press.

Temperini, Lino. 1998. Giovanna della Croce 1481-1534. Mistica e reformatrice. Santi e santità nel movimento penitenziale francescano dal Duecento al Cinquecento. Atti del Convegno di Studi Francescani. Assisi, 11-12 febbraio 1998, Rome: Analecta Tertii Ordinis Regularis Sancti Francisci, 43-74.

Triviño, María Victoria. 1999. Mujer, predicadora y párroco. La Santa Juana (1481-1534). Madrid: BAC.

Triviño, María Victoria. 2004. El arte al servicio de la predicación. "La Santa Juana" (1481-1534). Franciscana de la TOR. In La clausura femenina en España: actas del simposium: 1/4-IX-2004. Edited by Francisco Javier Campos and Fernández de Sevilla. Madrid: Real Centro Universitario Escorial-María Cristina, vol. 2, pp. 1251-70.

Triviño, María Victoria. 2011. El libro que da forma a la vida claustral: la regla de Santa Clara en los 800 años de la fundación de las clarisas. In La clausura femenina en el Mundo Hispánico. Una fidelidad secular: Simposium (XIX Edición) San Lorenzo del Escorial, 2 al 5 de septiembre. Edited by Francisco Javier Campos y Fernández de Sevilla. Madrid: Real Centro Universitario Escorial-María Cristina, vol. 1, pp. 425-48.

Triviño, María Victoria. 2019. Mujer, predicadora y párroco. La Santa Juana (1481-1534). Madrid: BAC.

Tylus, Jane. 2013. Writing versus Voice: Tommaso Caffarini and the Production of a Literate Catherine. In Catherine of Siena: The Creation of a Cult. Edited by Jeffrey F. Hamburger and Gabriela Signori. Turnhout: Brepols, pp. 291-314.

Ulibarrena, Juana Mary Arcelus. 1994. Santa Clara de Asís en el ‘Floreto de San Francisco' (Sevilla, 1492). Supplement of Verdad y vida LII (205-306): 211-25.

Ulibarrena, Juana Mary Arcelus. 1998. Floreto de Sant Francisco [Sevilla, 1492]. "Fontes Franciscani" y literatura en la península Ibérica y el Nuevo Mundo. Estudio crítico, texto, glosario y notas. Salamanca: Universidad Pontificia de Salamanca.

Vanderputten, Steven. 2013. Monastic Reform as a process. Realities ans Representations in Medieval Flanders, 900-1100. Ithaca and London: Cornell University Press.

Vauchez, André. 1988. La sainteté en Occident aux derniers siècles du Moyen Age. Rome: École française de Rome.

Warr, Cornelia. 2010. Dressing for Heaven: Religious Clothing in Italy, 1215-1545. Manchester and New York: Manchester University Press.

Zarco Cuevas, Julián. 1924-1929. Catálogo de los manuscritos castellanos de la Real Biblioteca de El Escorial. Madrid: Imprenta Helénica, 3 vols.

Zarri, Gabriela. 1980. Le sante vive. Per una tipologia della santità femminile nel primo Cinquecento. Annali dell'Istituto storico italo-germanico in Trento 6: 371-445.

Zarri, Gabriella. 1990. Le Sante vive: profezie di corte e devozione femminile tra '400 e '500. Torino: Rosenberg \& Sellier.

Zarri, Gabriella. 2010. Places and Gestures of Women's Preaching in Quattro- and Cinquecento Italy. In Charisma and Religious Authority: Jewish, Christian, and Muslim Preaching, 1200-1500. Edited by Katherine L. Jansen. Turnhout: Brepols, pp. 177-93.

Zarri, Gabriella. 2011. Chiara Bugni e Francesco Zorzi suo biografo: Saggio introduttivo. In La Vita e i Sermoni di Chiara Bugni, clarissa veneziana (1471-1514). Edited by Reinhold C. Mueller and Gabriella Zarri. Rome: Edizioni di Storia e Letteratura, pp. XI-XXXIX.

Zarri, Gabriella. 2014. La scrittura monastica. In Letras en la celda. Cultura escrita de los conventos femeninos en la España moderna. Edited by Nieves Baranda Leturio and María del Carmen Marín Pina. Madrid and Frankfurt am Main: Iberoamericana-Vervuert, pp. $49-64$.

Zarri, Gabriella, and Nieves Baranda Leturio. 2011. Memoria e comunità femminili. Spagna e Italia, secc. XV-XVII. Memoria y comunidades femeninas. España e Italia, siglos XV-XVII. Florence: Firenze UP and UNED.

Zugasti. 2017. Santidad bajo sospecha: la vida de Sor Juana de la Cruz (1481-1534) en florilegios de santos, crónicas y escenarios del Siglo de Oro. In Digital edition from Hommage à André Gallego. La transmission de savoirs licites ou illicites dans le monde hispanique péninsulaire (XIIe au XVIIe siècles). Edited by Luis González Fernández and Teresa Rodríguez. Toulouse: CNRS-Université de Toulouse-Le Mirail, Alicante: Biblioteca Virtual Miguel de Cervantes, pp. 339-67. First published 2011. Available online: http:/ / www.cervantesvirtual.com/obra/santidad-bajo-sospecha-la-vida-de-sor-juana-de-la-cruz-1481-153 4-en-florilegios-de-santos-cronicas-y-escenarios-del-siglo-de-oro-780010/ (accessed on 20 March 2021). 